\section{Review Article}

Check for updates

\title{
Optimization of Percutaneous Coronary Intervention Using Optical Coherence Tomography
}

\author{
Cheol Hyun Lee $\mathbb{B}$, MD and Seung-Ho Hur $\mathbb{1}$, MD, PhD, FACC \\ Division of Cardiology, Department of Internal Medicine, Keimyung University Dongsan Hospital, Daegu, \\ Korea
}

\begin{abstract}
Received: Jun 27, 2019
Accepted: Jul 3, 2019

Correspondence to

Seung-Ho Hur, MD, PhD, FACC

Division of Cardiology, Department of Internal

Medicine, Keimyung University Dongsan

Hospital, 1035 Dalgubeol-daero, Dalseo-gu,

Daegu 42601, Korea.

E-mail: shur@dsmc.or.kr

Copyright (c) 2019. The Korean Society of Cardiology

This is an Open Access article distributed under the terms of the Creative Commons Attribution Non-Commercial License (https:// creativecommons.org/licenses/by-nc/4.0) which permits unrestricted noncommercial use, distribution, and reproduction in any medium, provided the original work is properly cited.

ORCID iDs

Cheol Hyun Lee (iD)

https://orcid.org/0000-0003-4203-1457

Seung-Ho Hur iD

https://orcid.org/0000-0002-3895-1915
\end{abstract}

Conflict of Interest

The authors have no financial conflicts of interest.

\section{Author Contributions}

Writing - original draft: Lee $\mathrm{CH}$, Hur SH;

Writing - review \& editing: Hur SH.

\begin{abstract}
Compared to the luminogram obtained by angiography, intravascular modalities produce cross-sectional images of coronary arteries with a far greater spatial resolution. It is capable of accurately determining the vessel size and plaque morphology. It also eliminates some disadvantages such as contrast streaming, foreshortening, vessel overlap, and angle dependency inherent to angiography. Currently, the development of its system and the visualization of coronary arteries has shown significant advancement. Of those, optical coherence tomography (OCT) makes it possible to obtain high-resolution images of intraluminal and transmural coronary structures leading to navigation of the treatment strategy before and after stent implantations. The aim of this review is to summarize the published data on the clinical utility of OCT, focusing on the use of OCT in interventional cardiology practice to optimize percutaneous coronary intervention.
\end{abstract}

Keywords: Coronary artery disease; Percutaneous coronary intervention; Optical coherence tomography

\section{INTRODUCTION}

Despite the development of many technologies in the era of percutaneous coronary intervention (PCI) since its introduction in 1977, coronary angiography (CAG) is still used as a gold standard to diagnose coronary artery disease, determine the treatment strategy, and evaluate the therapeutic effect. However, it is also true that CAG has several limitations. Therefore, the intravascular imaging method has been introduced to overcome the drawbacks of CAG. Intravascular ultrasound (IVUS) has better resolution than CAG. It provides a cross-sectional image and more information than CAG. Thus, it can broaden the horizon and understanding of coronary artery disease. IVUS findings provide important information to physicians before and after coronary stenting. For example, the minimal stent area (MSA) among the IVUS parameters is known to be a predictor of a long-term major adverse cardiovascular event (MACE). ${ }^{122}$ Until now, IVUS-guided PCI has been classified as Class IIa for a left main (LM) PCI or stent optimization in the American College of Cardiology/ American Heart Association (ACC/AHA) and European Society of Cardiology (ESC) guidelines. ${ }^{344)}$ However, since a meta-analysis has proven its hard endpoint reduction effect 
including mortality, it tends to be used more often in practice or complex PCI procedures. ${ }^{5 / 6)}$ Currently, IVUS is regarded as an essential tool for PCI optimization in complex lesions. Although intravascular optical coherence tomography (OCT) has a shorter history than IVUS, it has a 10 times higher resolution and provides more information than IVUS. In addition, the development of a user interface for OCT has led to a more accurate approach for stent optimization, including information on the stent expansion, edge dissections, stent apposition, and tissue protrusions (TPs). As the experience of OCT-guided PCI accumulates, the recommendation level of OCT for stent optimization in 2018 ESC/European Association for Cardio-Thoracic Surgery (EACTS) guidelines has been upgraded from Class IIb to Class IIa.7) Therefore, this article reviews the details, methods, and clinical implications of OCT for PCI optimization.

\section{LIMITATIONS OF CORONARY ANGIOGRAPHY}

CAG is still accepted as a gold standard for the diagnosis and treatment of coronary artery disease. ${ }^{899}$ However, CAG has a limitation as a luminogram in that it can only reveal a change in the lumen. It is difficult to identify changes that appear in the early stage of coronary artery disease with CAG because it can only detect the late process of atherosclerosis such as luminal stenosis. Another serious limitation of CAG is that it is prone to functionally overestimating or underestimating the lesion because only a secondary shadow image is examined (Figure 1). ${ }^{9-11}$ It is also difficult to judge the degree of the lesion severity, especially of complex lesions such as diffuse long lesions, bifurcation lesions, and calcified lesions. More importantly, the lesion has to be assessed through visual estimation. Thus, the evaluation of the lesion is inevitably subjective and is prone to have various errors in evaluating target lesions, selecting the treatment strategy, and determining the treatment results through CAG guidance only.
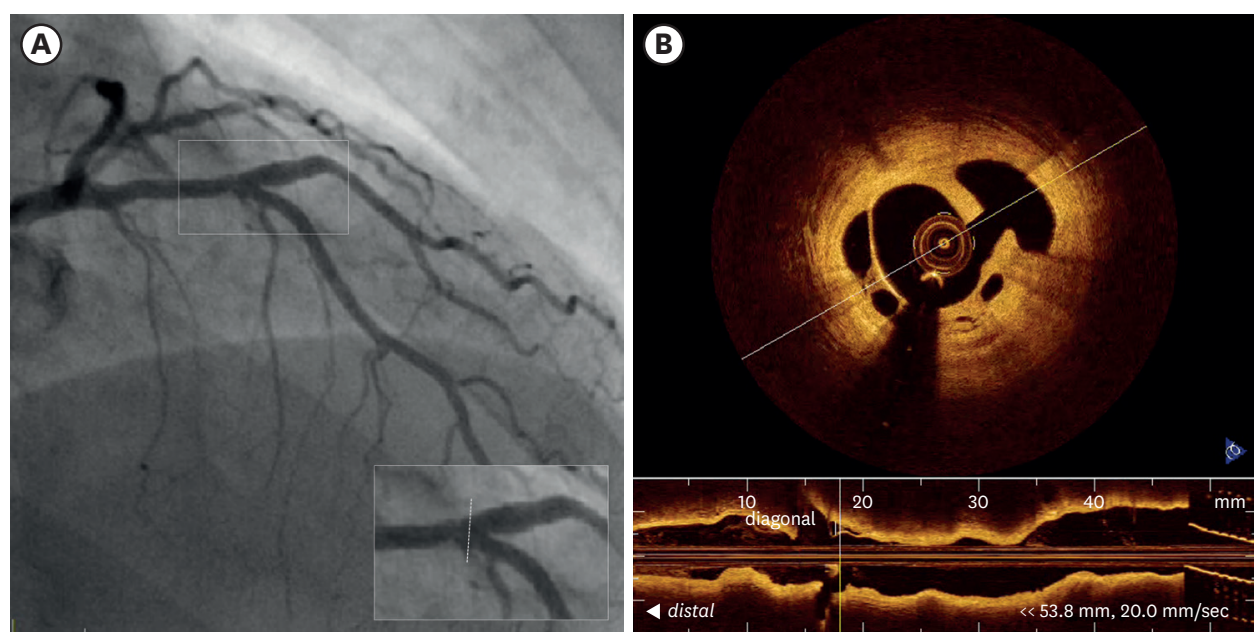

Figure 1. A representative case demonstrating a discrepancy between coronary angiography and OCT. The right anterior oblique cranial projection of the left coronary angiogram showing mild stenosis at an LAD bifurcation lesion (A). However, OCT clearly demonstrates a focal (2 mm length) lotus root-like lesion consisting of multiple cavities with septation, which was not seen by coronary angiography (B). Modified from Korean J Intern Med 2016;31:807-808.

$\mathrm{LAD}=$ left anterior descending; OCT = optical coherence tomography. 


\section{INTRAVASCULAR IMAGING}

To compensate for the limitations of CAG, imaging modalities including IVUS and OCT have been developed for use in clinical practice. IVUS can provide a cross-sectional image of the vessel wall similar to the histological findings using high ultrasound frequencies of 20 to $50 \mathrm{MHz} .{ }^{12)}$ Thus, IVUS allows a qualitative and quantitative assessment of the lumen, plaque, and vessel in coronary atherosclerotic lesions. On the other hand, OCT can generate a tomographic image using backscattered infrared light with an axial resolution of 12-15 $\mu \mathrm{m} .{ }^{13)}$ Similar to IVUS, OCT can also provide qualitative and quantitative information for the lesion. However, OCT has several advantages for PCI optimization. First, OCT provides more detailed features (such as the presence of thrombi, plaque erosions, and the cap thickness) of the vascular wall that IVUS cannot detect. Thus, OCT is a better choice for detecting vulnerable plaque. Second, the pullback speed of OCT is faster than that of IVUS. In addition, OCT provides an automated analysis of the minimal and maximal diameters and lumen dimension of the entire area. Moreover, OCT can automatically point to the position of the minimal lumen area (MLA) in the lesion. Third, OCT can provide a more accurate assessment of the interaction with the vessel wall and stent (e.g., stent apposition, stent coverage, TPs, and edge dissections) due to its superior axial and lateral resolution power. The OPUS-CLASS study ${ }^{14)}$ performed measurements of the coronary arteries using OCT, IVUS, and CAG. The mean minimum lumen diameter (MLD) measured by CAG was significantly smaller than that measured by OCT while the MLD measured by IVUS was significantly greater than that measured by OCT. Using a phantom model, it was found that the mean lumen area measured by OCT was the same as the actual lumen area. However, IVUS overestimated the lumen area compared to OCT (relative reference 10\%), suggesting that OCT might be more accurate for assessing coronary lesions than IVUS or CAG. Our previous study ${ }^{15}$ had also shown discrepancies among OCT, IVUS, and CAG measurements for a phantom coronary model and human coronary arteries within and adjacent to stented segments. The discrepancy between IVUS and OCT was less prominent, with each measurement showing a stronger correlation for the stented segment than that for the reference segment. That was probably because the stent struts provided a clear landmark for the lumen discrimination in both OCT and IVUS for stented segments. For a phantom model and human coronary arteries, for IVUS as compared to OCT, the lumen area was larger, particularly for non-stented segments than for stented segments. The lumen diameter measured by CAG was smaller than that measured by IVUS or OCT. Based on these two studies, the lumen area measured by OCT is likely to be smaller than that measured by IVUS, particularly for non-stented segments than stented segments. The lumen diameter measured by CAG was smaller than that measured by IVUS or OCT. In addition, OCT could accurately and quantitatively measure the coronary artery dimensions in the clinical setting with a high reproducibility. However, in the post-stent evaluation, the discrepancy between IVUS and OCT was insignificant.

\section{OPTICAL COHERENCE TOMOGRAPHY PARAMETERS FOR PERCUTANEOUS CORONARY INTERVENTION GUIDANCE}

\section{Pre-intervention}

The role of OCT in pre-intervention is for the lesion evaluation. The plaque composition may guide the implementation of a preparation strategy. For vulnerable plaque such as that with a large lipid content or thin cap, and expansive remodeling lesions, direct stenting is an option without predilatation. Since calcified lesions may not be detected by CAG ${ }^{16)}$ an OCT-guided 
PCI might be needed. For calcified lesions, OCT can accurately quantitate both its extent and severity. Thus, it can help physicians make a decision regarding the use of rotablation or cutting balloon for the lesion preparation and the selection of the device. Compared to IVUS, OCT can analyze the depth of calcified lesions in addition to a circumferential arc. Therefore, OCT can precisely measure the calcified lesion area that is known to be associated with underexpansion of stents. ${ }^{1719)}$ In addition, the detailed information provided by OCT can be used to guide a calcified lesion preparation. For example, balloon dilatation for calcified plaques with a low thickness and wide arc on OCT (with cut-off values of $0.67 \mathrm{~mm}$ and $227^{\circ}$, respectively) can lead to calcium fractures that are known to be associated with a better stent expansion. ${ }^{17)}$ Similarly, an OCT-based study showed that calcified lesions with a maximum angle of $>180^{\circ}$, maximum thickness of $>500 \mu \mathrm{m}$, and length of $>5 \mathrm{~mm}$ had increased the risk of stent underexpansion. ${ }^{20}{ }^{2}$ However, the effect of calcified lesions on the outcomes of a clinical PCI remains unclear. OCT-detected large proportions of lipid plaque and thin-cap fibroatheromas (TCFAs) are known to be associated with a peri-procedural myocardial infarction (MI).2127) Owing to the correlation between edge problems in-stent thrombosis (ST) and MACE, ${ }^{26-34}$ it might be required to avoid reference segments with large proportions of lipid plaque, particularly those with TCFAs. If lipid is unavoidable in the reference segment, covering the entire lipidrich plaque with a stent instead of ending the stent in the middle of a lipidic region has been suggested. ${ }^{28-36}$ More importantly, either the external elastic lamina (EEL) or the lumen diameter at the reference segments measured by OCT can provide the roadmap for stent sizing. There are two representative studies related to stent sizing. The Observational Study of Optical Coherence Tomography in Patients Undergoing Fractional Flow Reserve and Percutaneous Coronary Intervention (ILUMIEN) III: OPTIMIZE PCI used an EEL-based stent sizing while the Optical Frequency Domain Imaging vs. Intravascular Ultrasound in Percutaneous Coronary Intervention (OPINION) used a lumen-based stent sizing (Table 1). In the ILUMIEN III trial, the maximum and minimum diameters of the EEL at the proximal and distal reference segments

Table 1. Summary of the absolute and relative stent expansion criteria for stent optimization (data from IVUS and OCT studies)

\begin{tabular}{|c|c|c|c|c|}
\hline Study/first author, year & Location & Contour in reference segment & Reference segment & Criteria \\
\hline \multicolumn{5}{|l|}{ OCT studies } \\
\hline OCTACS, $2015^{69)}$ & Entire segment & Lumen & Average ref. LA & MSA $\geq 90 \%$ of the average ref. LA \\
\hline \multirow[t]{2}{*}{$\begin{array}{l}\text { ILUMIEN III; OPTIMIZE PCI, } \\
2016^{37)}\end{array}$} & $\begin{array}{l}\text { Proximal and } \\
\text { distal segment }\end{array}$ & EEL & Proximal ref. EEL-EEL & $\begin{array}{l}\text { Proximal MSA }>90-95 \% \text { (acceptable) or } \geq 95 \% \\
\text { (optimal) of the proximal ref. LA }\end{array}$ \\
\hline & & & Distal ref. EEL-EEL & $\begin{array}{l}\text { Distal MSA }>90-95 \% \text { (acceptable) or } \geq 95 \% \\
\text { (optimal) of the distal ref. LA }\end{array}$ \\
\hline OPINION, 201738) & Entire segment & Lumen & Average ref. LA & MSA $\geq 90 \%$ of the average ref. LA \\
\hline DETECT-OCT, 2018 & Entire segment & Lumen & Distal ref. LA & $\mathrm{MSA}>4.0 \mathrm{~mm}^{2}$ \\
\hline \multicolumn{5}{|l|}{ IVUS studies } \\
\hline MUSIC, 1998 & Entire segment & Lumen & Average ref. LA & $\begin{array}{l}\text { MSA } \geq 90 \% \text { of the average ref. LA or } \geq 100 \% \text { of } \\
\text { the LA of ref. segment with the lowest LA }\end{array}$ \\
\hline HOME-DES IVUS, 201049) & Entire segment & Lumen & Distal ref. LA & $\begin{array}{l}\text { MSA } \geq 5.0 \mathrm{~mm}^{2} \text { or MSA }>90 \% \text { of the distal ref. } \\
\text { lumen MSA for small vessels }\end{array}$ \\
\hline
\end{tabular}

Average ref. LA = (proximal + distal) reference LA/2; CLI-OPCI = Centro per la Lotta Contro L'Infarto-Optimization of Percutaneous Coronary Intervention; DETECT-OCT = DETErmination of the Duration of the Dual Antiplatelet Therapy by the Degree of the Coverage of The Struts on Optical Coherence Tomography; DOCTORS = Does Optical Coherence Tomography Optimize Results of Stenting; EEL = external elastic lamina; ILUMIEN = Observational Study of Optical Coherence Tomography in Patients Undergoing Fractional Flow Reserve and Percutaneous Coronary Intervention; HOME-DES IVUS = Long-Term Health Outcome and Mortality Evaluation After Invasive Coronary Treatment using Drug Eluting Stents with or without the IVUS Guidance; IVUS = intravascular ultrasound; IVUS XPL = The Impact of Intravascular Ultrasound Guidance on Outcomes of Xience Prime Stents in Long Lesions; LA = lumen area; MLA, minimal lumen area; MSA = minimal stent area; MUSIC = Multicenter Ultrasound Stenting in Coronaries; OCT = optical coherence tomography; OCTACS = Optical Coherence Tomography Guided Percutaneous Coronary Intervention With Nobori Stent Implantation in Patients With Non-ST-Segment-Elevation Myocardial Infarction; OPINION = Optical Frequency Domain Imaging vs. Intravascular Ultrasound in Percutaneous Coronary Intervention; $\mathrm{PCl}=$ percutaneous coronary intervention. 
were measured and the mean EEL diameter of each reference was calculated. The smaller of the two mean EEL diameters was rounded down to the nearest $0.25 \mathrm{~mm}$ to derive the stent diameter (e.g., $3.40 \mathrm{~mm}$ round down to $3.25 \mathrm{~mm}$ ) ${ }^{377}$ In the OPINION trial, the cross-sections that were close to the target lesion with the most normal appearance that had no lipidic plaque were set as the proximal and distal reference sites. After measuring the lumen diameter at the proximal and distal reference sites, the stent diameter was then calculated. The stent length was determined as the distance between the proximal and distal reference segments. ${ }^{38)} \mathrm{A}$ representative case and illustration of the stent sizing are shown in Figures $\mathbf{2}$ and $\mathbf{3}$, respectively. Intriguingly, the OPTIS integrated (OPTISi) angiographic co-registration system consists of the tracking radiopaque lens marker of the OCT catheter on a cine acquired during the OCT pullback. The software of the OPTISi system directly displays a matched side-by-side view of the OCT and angiography in the cath lab and eliminates the need for the currently used standalone, mobile OCT carts. A small white marker is directly projected onto the angiogram to pinpoint the corresponding site of the displayed OCT frame. Co-registration allows "mapping" of coronary lesions on the angiographic roadmap (error margin approximately $1 \mathrm{~mm}$ ). By using the OPTIS system, the stent length and location of the plaque can be linked to the angiography findings. It can be performed to carry out a more accurate intervention (Figure 4). ${ }^{39}$ )

\section{Post-intervention}

Stent underexpansion is an important risk factor of stent failure. ${ }^{40) 41)}$ Stent expansion refers to the minimum cross-sectional area (CSA) of a stent as an absolute measurement (absolute stent expansion) or compared to a predetermined reference site that can be the proximal, distal, largest, or average reference site (relative stent expansion). In principle, a greater absolute stent expansion is associated with better stent-related clinical outcomes and a lower risk of stent failure. ${ }^{41-43)}$ Compared to the relative stent expansion, the absolute stent expansion appeared to be able to better predict the stent patency. Regarding the absolute stent expansion, some studies have shown strong evidence that IVUS is useful for non-left main (non-LM) lesions and the drug-eluting stent (DES) era with a cut-off of $>5 \mathrm{~mm}^{2}{ }^{41144)}$ IVUS studies with second-generation DESs demonstrated that a stent CSA of $5.5 \mathrm{~mm}^{2}$ is the best cut-off for subsequent events in non-LM lesions. ${ }^{4144)}$ IVUS studies with secondgeneration DESs have relatively consistently demonstrated that a stent CSA of $5.5 \mathrm{~mm}^{2}$ is the best cut-off for subsequent events in non-LM lesions. ${ }^{\left.41)^{44}\right)}$ However, the cut-offs values for LM lesions are larger than that for non-LM lesions (by IVUS: distal LM $>7 \mathrm{~mm}^{2}$; proximal LM $\left.>8 \mathrm{~mm}^{2}\right)$. With OCT, the optimal cut-off to predict a post-procedural fractional flow reserve (FFR) of $>0.90$ was consistently found to be $>5.44 \mathrm{~mm}^{2}$ in the Does Optical Coherence Tomography Optimize Results of Stenting (DOCTORS) trial. ${ }^{45}$ However, the results from the Centro per la Lotta Contro L'Infarto-Optimization of Percutaneous Coronary Intervention (CLI-OPCI) II registries have revealed that an MLA of $4.5 \mathrm{~mm}^{2}$ is the best cut-off value for OCT to identify patients with MACEs. ${ }^{46}$ The current OPTIS OCT system enables the easy detection of the relative stent expansion and automated measurements after the stent deployment. The MSA and percentage of the stent expansion can be automatically calculated and highlighted after assigning markers for the site of interest that are close to the proximal and distal edges of the stent translating into a user-friendly tool during PCI. In terms of the relative stent expansion, the Multicenter Ultrasound Stenting in Coronaries (MUSIC) study criteria used a MSA of $>90 \%$ of the average reference lumen area or $>100 \%$ of a smaller reference lumen area with a complete apposition and symmetric expansion as the cut-off for IVUS ${ }^{47}$ The Impact of Intravascular Ultrasound Guidance on Outcomes of Xience Prime Stents in Long Lesions (IVUS XPL) criteria used a MSA $\geq$ the distal reference lumen area. ${ }^{48)}$ Although the absolute stent expansion criteria have been commonly used in several studies 

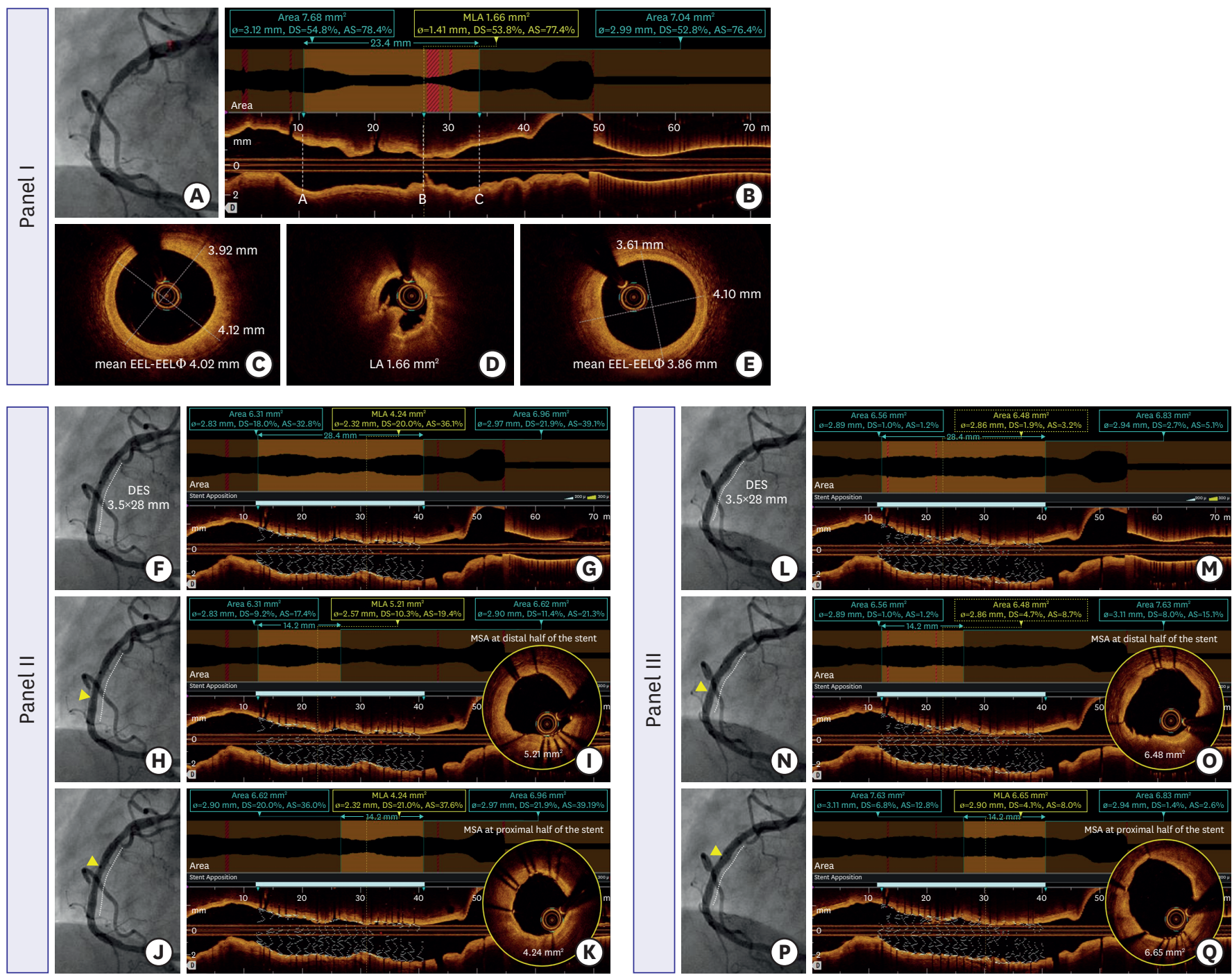

Figure 2. A representative case of an OCT-guided PCI (stent sizing and post-stent optimization). A 57-year old female patient with a non-ST segment myocardial infarction underwent CAG and an OCT examination before the intervention (panel I, A-E), after the stent implantation (panel II, F-K) and after additional balloon dilatation (panel III, L-Q). The baseline CAG revealed significant stenosis in the proximal right coronary artery (A). A longitudinal OCT image revealed a lesion length of $23.3 \mathrm{~mm}$ (B) and the cross-sectional OCT image revelaed a $1.66 \mathrm{~mm}^{2}$ lumen area with a red thrombus (C). Because the EEL contours were identifiable in both the proximal (C) and distal (D) reference segments, the mean EEL to EEL diameter was calculated. Of these, the lowest EEL to EEL diameter was $3.89 \mathrm{~mm}$ in the proximal reference segment $(E)$. Thus a $3.5 \times 28 \mathrm{~mm}$ Xience stent was chosen based on downsizing to the nearest stent diameter (3.5 $\mathrm{mm}$ ) from the lowest EEL to EEL diameter $(3.89 \mathrm{~mm})$ and was implanted with a 12 atmospheric pressure. After the stent implantation, a CAG showed a mild residual stenosis at the proximal portion within the stented segments (F) and the longitudinal OCT image showed that the MSA was $4.24 \mathrm{~mm}^{2}$ and was located at the proximal one-third portion within the stented segments $(G)$. Because a long stent $(228 \mathrm{~mm})$ was implanted in the proximal right coronary artery, the entire stented segments were divided by the stent length of $14 \mathrm{~mm}$, half the stent length, and the reference bar was moved to each distal and proximal stented segment for an evaluation of the optimal relative stent expansion. Then, the residual AS was manually calculated by the OPTIS system: [[\{1-(proximal (or distal) MSA/proximal (or distal) reference lumen area) $\} \times 100]=$ residual proximal (or distal) AS (\%)]. The longitudinal and cross-sectional OCT images showed that the MSA in the distal half of the stented segments was $5.21 \mathrm{~mm}^{2}$, which calculated that the residual distal AS value was $17.4 \%$ relative to distal reference lumen area: $[\{1-(5.21 / 6.31) \times 100\}=17.4 \%$ of AS] (I). Similarly, the MSA in the proximal half of the stented segments was $4.24 \mathrm{~mm}^{2}$, which calculated that the residual proximal AS value was $39.1 \%$ relative to proximal reference lumen area $[\{1-(4.24 / 6.96) \times 100\}=39.1 \%$ of AS] (K). Stent underexpansion was confirmed by these AS results (an acceptable stent expansion is defined as an AS of at least $<10 \%$ relative to each reference lumen area). The post-dilatation balloon size was determined by the EEL to EEL diameter of the proximal reference segment. Thus, post-dilatation was performed using a $3.75 \times 8 \mathrm{~mm}$ non-compliant balloon throughout the stented segments. After additional balloon dilatation, a CAG showed no residual stenosis within the stented segments (L). The longitudinal and cross-sectional OCT images showed that the MSA in the distal half of the stented segments improved from $5.21 \mathrm{~mm}^{2}$ to $6.48 \mathrm{~mm}^{2}$, which calculated that the residual distal AS value had reduced from $17.4 \%$ to $1.2 \%$ relative to the distal reference lumen area $[\{1-(6.48 / 6.56) \times 100\}=1.2 \%$ of AS] $(0)$. Similarly, the MSA in the proximal half of the stented segments improved from $4.24 \mathrm{~mm}^{2}$ to $6.65 \mathrm{~mm}^{2}$, suggesting that the residual proximal AS value had decreased from $39.1 \%$ to $2.7 \%$ relative to the proximal reference lumen area $[\{1-(6.65 / 6.83) \times 100\}=2.6 \%$ of AS $](Q)$. Based on the AS results post-dilatation, the stent optimization was confirmed without any complications.

$A S$ = area stenosis; $C A G=$ coronary angiography; $D S=$ diameter stenosis; $E E L=$ external elastic lamina; $\Phi=$ diameter; $M S A=$ minimal stent area; $M L A=$ minimal lumen area; $\mathrm{OCT}$ = optical coherence tomography; $\mathrm{PCl}$ = percutaneous coronary intervention. 


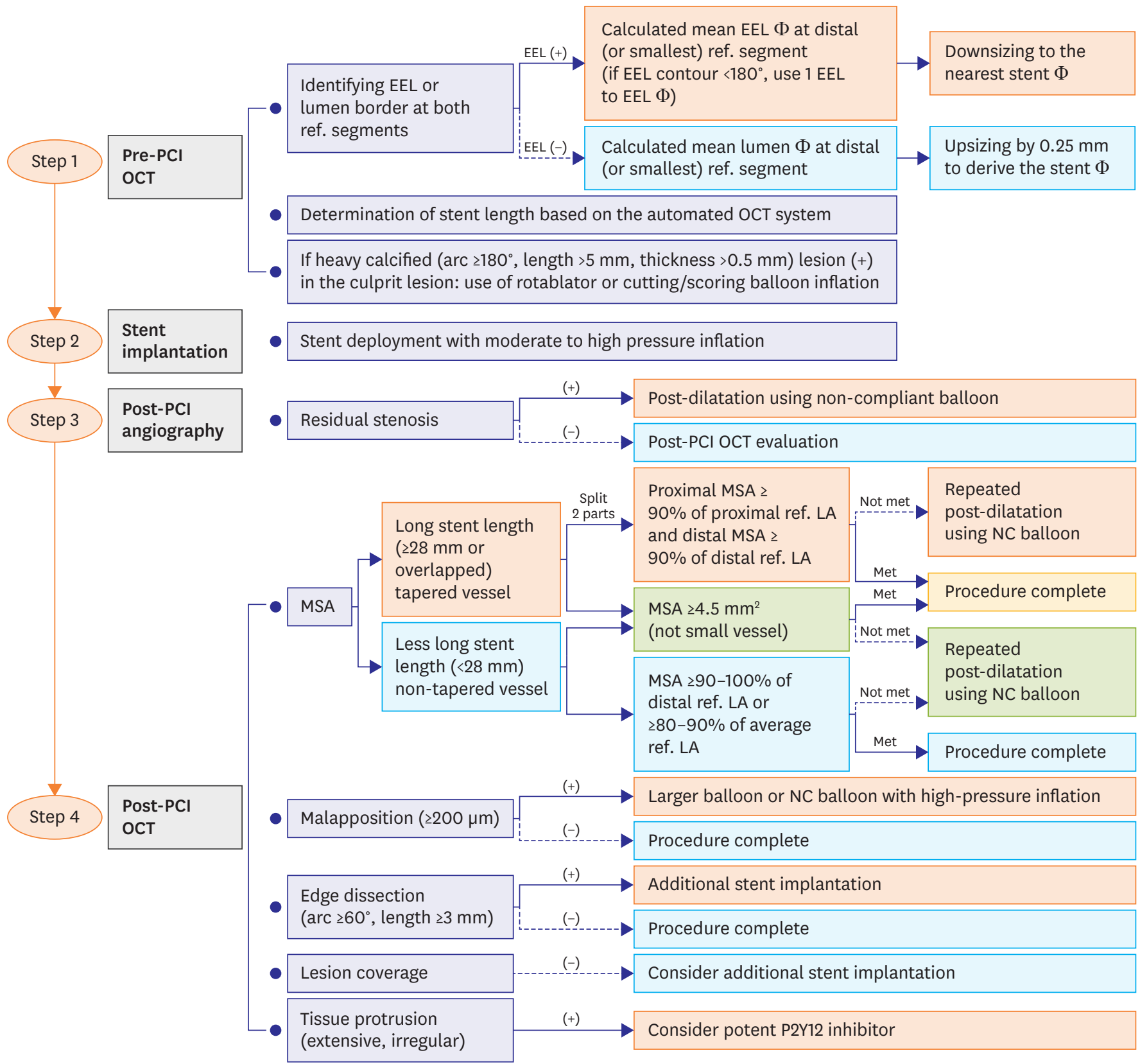

Figure 3. Stepwise procedure for the stent optimization under OCT guidance.

$\mathrm{EEL}=$ external elastic lamina; $\mathrm{PCl}=$ percutaneous coronary intervention; $\mathrm{OCT}=$ optical coherence tomography; $\Phi=$ diameter; $\mathrm{MSA}=$ minimal stent area; ref. = reference; $\mathrm{LA}=$ lumen area; $\mathrm{NC}=$ noncompliant. 

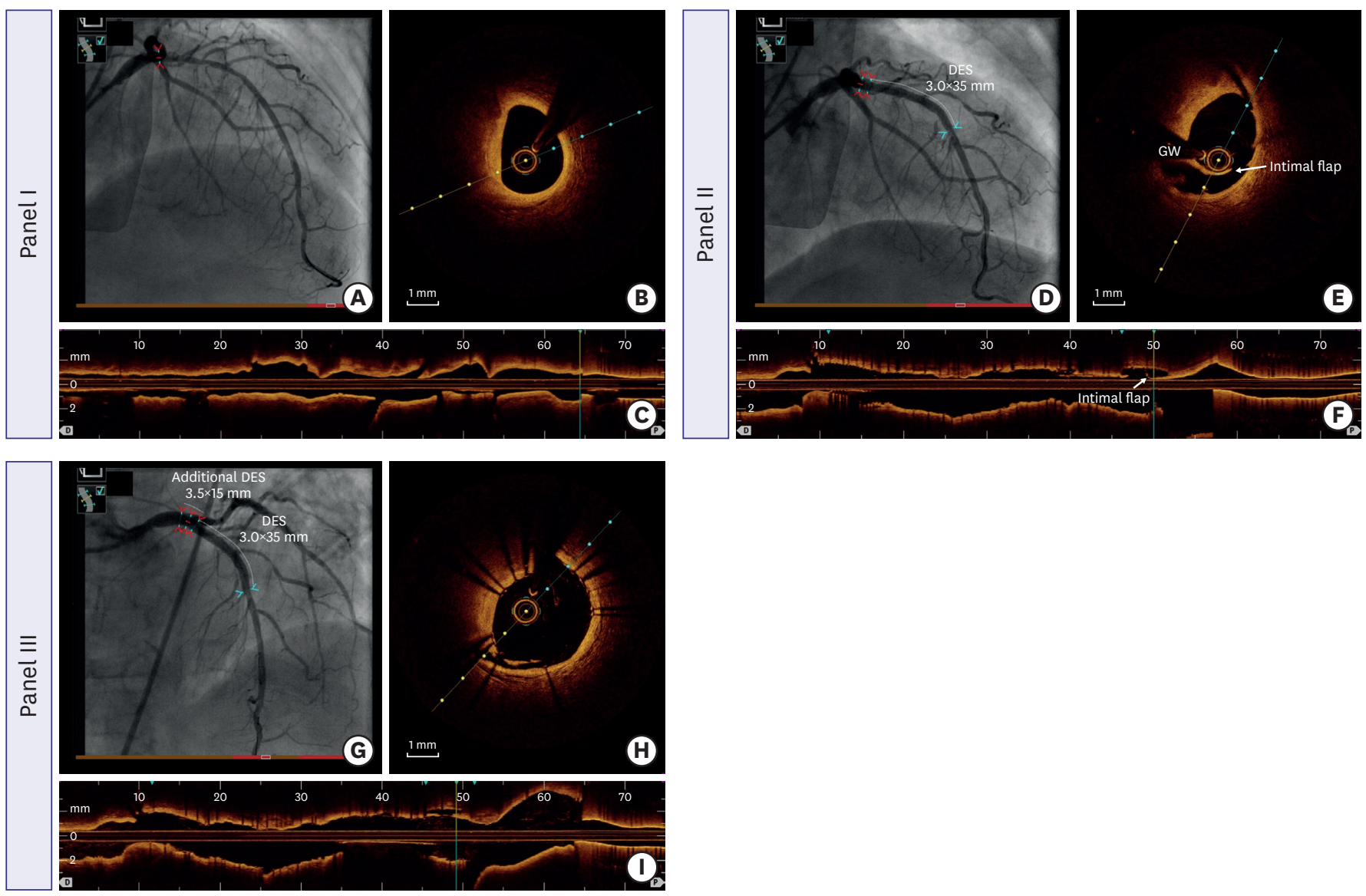

Figure 4. A representative case of an OCT-angiography coregistration. Preinterventional OCT-angiography coregistration (panel I, A-C). Angiographic coregistration (A) shows diffuse significant disease in the proximal portion of the LAD. The red arrowheads indicate the proximal reference segment. The corresponding cross-sectional OCT image (B) demonstrates a fibrous plaque with a preserved lumen area at the proximal reference segment, and the longitudinal OCT image (C) also shows diffuse significant disease in the proximal portion of the LAD. Post-stenting OCT-angiography coregistration (panel II, D-F). In the angiographic coregistration (D), the 2nd red arrowhead and sky-blue arrowhead indicate the stented segments (1st DES $3.0 \times 35 \mathrm{~mm})$. The 1st red arrowhead indicates the location of the proximal edge dissection. The corresponding cross-sectional OCT image (E) and longitudinal OCT image (F) show a severe dissection with an intimal flap. Thus, a 2nd DES $(3.5 \times 15 \mathrm{~mm})$ was implanted and the final OCT-angiography coregistration shows that the additional DES completely covered the prior proximal edge dissection (panel III, G-I).

$\mathrm{OCT}$ = optical coherence tomography; $\mathrm{DES}=$ drug-eluting stent; $\mathrm{GW}$ = guide wire; $\mathrm{LAD}$ = left anterior descending.

can be halved to attain $>90 \%$ of the average reference (proximal and distal) lumen area for the MSA in each proximal and distal stent segment based on considering natural vessel tapering. ${ }^{37}$ Another study suggested that a MSA of $>80 \%$ of the average reference lumen area can predict a FFR of $>0.90 .{ }^{45}$ Considering these data, the relative stent expansion criteria seem to be reasonable when the MSA is $>90 \%$ to $100 \%$ of the distal reference lumen area or $>80 \%$ to $90 \%$ of the average reference lumen area.

TP is an intra-stent protrusion of the tissue into the lumen between the stent struts..$^{50)}$ Some investigators have suggested an arbitrary definition of TP as an intraluminal mass (100-500 $\mu \mathrm{m})$ without any communication with the vessel wall or protruding tissue with a circular arc connecting adjacent struts (Table 2). ${ }^{51-55}$ Our small study showed that TPs were present in $95 \%$ of stented segments as viewed by OCT and in $45 \%$ of the stented segments as viewed by IVUS with the best cut-off values for the area, depth, and burden of the TP on the OCT to detect a TP on IVUS of $0.17 \mathrm{~mm}^{2}, 0.17 \mathrm{~mm}$, and $1.98 \%$, respectively. ${ }^{56)}$ Therefore, IVUS could not detect TPs in half of the patients. This is probably due to its limited resolution 
Table 2. Summary of the stent apposition, edge dissection, tissue protrusion, and reference luminal narrowing for stent optimization (data from OCT studies)

\begin{tabular}{|c|c|c|c|c|}
\hline Study, year & Stent apposition & Edge dissection & Tissue protrusion & Reference luminal narrowing \\
\hline $\begin{array}{l}\text { Imola et al., } \\
2010^{70)}\end{array}$ & $\begin{array}{l}\text { The distance between a strut } \\
\text { and vessel wall of } \leq 200 \mu \mathrm{m} \\
\text { and a length }<600 \mu \mathrm{m}\end{array}$ & $\begin{array}{l}\text { No disruption in the luminal vessel } \\
\text { surface at the edge segments (within } 5 \\
\mathrm{~mm} \text { proximal and distal to the stent) }\end{array}$ & $\begin{array}{l}\text { The distance from the stent struts } \\
\text { to the greatest extent of } \\
\text { a protrusion of } \leq 100 \mu \mathrm{m}\end{array}$ & NA \\
\hline $\begin{array}{l}\text { CLI-OPCI, } \\
2012^{62)}\end{array}$ & $\begin{array}{l}\text { A stent lumen distance } \\
\leq 200 \mu \mathrm{m}\end{array}$ & $\begin{array}{l}\text { The presence of a linear rim of tissue, } \\
\text { with a width of }<200 \mu \mathrm{m} \text { and a clear } \\
\text { separation from the vessel wall or } \\
\text { plaque }(<5 \mathrm{~mm}) \text { to the stent edge }\end{array}$ & $\begin{array}{l}\text { Intraluminal mass of }<200 \mu \mathrm{m} \text { with } \\
\text { no direct continuity with the vessel } \\
\text { wall or a highly back scattered } \\
\text { luminal protrusion in continuity } \\
\text { with the vessel wall }\end{array}$ & $\mathrm{LA} \geq 4.0 \mathrm{~mm}^{2}$ \\
\hline $\begin{array}{l}\text { CLI-OPCI II, } \\
2015^{46)}\end{array}$ & $\begin{array}{l}\text { A stent-adjacent vessel } \\
\text { lumen distance } \leq 200 \mu \mathrm{m}\end{array}$ & $\begin{array}{l}\text { The presence of a linear rim of tissue } \\
\text { with a width }<200 \mu \mathrm{m} \text { and a clear } \\
\text { separation from the vessel wall or } \\
\text { underlying plaque }<5 \mathrm{~mm} \text { to the } \\
\text { stent edge }\end{array}$ & $\begin{array}{l}\text { Tissue prolapsing between } \\
\text { stent struts with a circular arc } \\
\text { connecting adjacent struts or } \\
\text { intraluminal mass of }<500 \mu \mathrm{m} \text {, with } \\
\text { no continuity with the vessel wall }\end{array}$ & $\begin{array}{l}\mathrm{LA} \geq 4.5 \mathrm{~mm}^{2} \text { in the presence } \\
\text { of significant residual } \\
\text { plaque adjacent to the stent } \\
\text { endings }\end{array}$ \\
\hline $\begin{array}{l}\text { OCTACS, } \\
2015^{69)}\end{array}$ & $\begin{array}{l}<3 \text { struts per CSA detached } \\
\leq 140 \mu \mathrm{m} \text { from the underlying } \\
\text { vessel wall }\end{array}$ & Insignificant (causing $M L A \geq 4 \mathrm{~mm}^{2}$ ) & NA & $\begin{array}{l}\text { Insignificant residual } \\
\text { stenosis }\left(M L A \geq 4 \mathrm{~mm}^{2}\right)\end{array}$ \\
\hline $\begin{array}{l}\text { ILUMIEN III; } \\
\text { OPTIMIZE PCI, } \\
2016^{37)}\end{array}$ & $\begin{array}{l}\text { Struts clearly separated from } \\
\text { the vessel wall by }<200 \mu \mathrm{m}\end{array}$ & $\begin{array}{l}\text { Minor: any visible edge dissection of } \\
<60^{\circ} \text { of the circumference of the vessel } \\
\text { and }<3 \mathrm{~mm} \text { in length }\end{array}$ & $\begin{array}{l}\text { A protrusion is defined as any } \\
\text { mass at }<200 \mu \mathrm{m} \text { beyond the } \\
\text { luminal edge of a strut }\end{array}$ & $\begin{array}{l}\text { Untreated mean LA of } \leq 60 \% \\
\text { of the adjacent reference } \\
\text { segment LA of up to } 10 \mathrm{~mm} \\
\text { from both stent edges }\end{array}$ \\
\hline $\begin{array}{l}\text { OPINION, } \\
2017^{38)}\end{array}$ & $\begin{array}{l}\text { Complete apposition over } \\
\text { the entire length }\end{array}$ & $\begin{array}{l}\text { No edge dissection with the potential } \\
\text { to provoke a flow disturbance }\end{array}$ & $\begin{array}{l}\text { No tissue protrusion with the } \\
\text { potential to provoke a flow } \\
\text { disturbance }\end{array}$ & NA \\
\hline
\end{tabular}

$\mathrm{CLI}-\mathrm{OPCl}=$ Centro per la Lotta Contro L'Infarto-Optimization of Percutaneous Coronary Intervention; CSA = cross-sectional area; ILUMIEN = Observational Study of Optical Coherence Tomography in Patients Undergoing Fractional Flow Reserve and Percutaneous Coronary Intervention; LA = lumen area; MLA = minimal lumen area, NA = not available; OCT = optical coherence tomography; OCTACS = Optical Coherence Tomography Guided Percutaneous Coronary Intervention With Nobori Stent Implantation in Patients With Non-ST-Segment-Elevation Myocardial Infarction; OPINION = Optical Frequency Domain Imaging vs. Intravascular Ultrasound in Percutaneous Coronary Intervention; $\mathrm{PCl}=$ percutaneous coronary intervention.

compared to OCT. One registry reported that OCT-detected TPs can be classified into three categories based on the extent of the vessel injury: smooth protrusions with minimal vessel injury, disrupted fibrous TPs with mild vessel injury, and irregular protrusions with moderate to severe vessel injury and a high possibility of medial disruption and a lipid core penetration. ${ }^{57)}$ Among these different patterns, the irregular protrusions may be associated with adverse outcomes in a large cohort. ${ }^{57)}$ The OCT findings of TPs after stent implantations have been reported to be associated with early stent thrombosis and a poor short-term prognosis after PCI. ${ }^{301545) 5859)}$ The volume of the protruding tissue as viewed by OCT is associated with an unstable plaque feature and peri-procedural MIs. ${ }^{60)}$ The CLI-OPCI and Harmonizing Outcomes with Revascularization and Stents in Acute Myocardial Infarction (HORIZONS-AMI) sub-studies showed that TPs during acute coronary syndrome (ACS) are more likely to have consequences than those in non-ACS patients in the clinical setting. ${ }^{30)}$ Nevertheless, numerous IVUS and OCT studies have reported that the presence of a TP may not be associated with unfavorable long-term clinical outcomes in both ACS and non-ACS patients. ${ }^{54555(6)}$ Given the lesser evidence of its clinical relevance, the physician may attempt to avoid an extensive irregular TP after a stent implantation at the present time.

Stent edge dissections can usually be detected by OCT. However, they may not be detected by $\mathrm{CAG} .{ }^{37)}$ Edge dissection is defined as a linear rim of tissue adjacent to a stent edge ( $<5$ $\mathrm{mm}$ ) with a width of $\geq 200 \mu \mathrm{m}$. ${ }^{(2)}$ Different factors can affect the edge dissection, including the dissection depth/location/length, dissection flap angle, and residual lumen area at the dissection site. ${ }^{37(62)(63)}$ In ILUMIEN III, edge dissections were defined as being major by OCT when they extend in an arc of $>60^{\circ}$ and were $>3 \mathrm{~mm}$ in length based on the Assessment of Dual Antiplatelet Therapy With Drug-Eluting Stents (ADAPT-DES) registry data. ${ }^{35}$ Edge dissections at the distal stent edge as viewed by OCT, but not the proximal stent edge, were revealed to be an independent predictor of a MACE (hazard ratio [HR], 2.5) in the CLI-OPCI 
study ${ }^{(2)}$ Overall, additional intervention may not be needed unless there is an extensive edge dissection with or without a flow limitation.

Stent malapposition refers to the lack of contact of the stent struts with the vessel wall of $\geq 200 \mu \mathrm{m}$ as viewed by OCT. Underexpansion and stent malapposition can co-exist and can also occur independently. Moreover, malapposition can appear in different stages (acute, post-procedural, or late stage) possibly due to the underlying vascular process of inflammation and/or positive remodeling of the vessel wall. A malapposition indicator can be accessed with the OPTIS OCT system as it can highlight areas of the stent that have become disconnected from the vessel wall (Figure 5). Although an acute stent malapposition can be easily detected with OCT, its clinical outcomes remain controversial. Several studies have reported that an acute stent malapposition is not associated with adverse clinical outcomes, ${ }^{64(65)}$ whereas a high frequency of malappositions has been observed in patients with acute and late stent thromboses. ${ }^{66) 67}$ Thus, when a malapposition is greater than $500 \mu \mathrm{m}$, (particularly when it is continuous with a length of $>1 \mathrm{~mm}$ ) and the malapposition exhibits an underexpansion that can deteriorate into a turbulent flow, and when a malapposition occurs in the proximal stented segments that may make the re-entry in the vessel difficult, an additional procedure might be needed ${ }^{68}$ Nevertheless, several studies have addressed that stent malappositions of $<200 \mu \mathrm{m}$ may be acceptable for stent optimization. ${ }^{46(6)(69)}$

\section{OPTIMIZATION OF PERCUTANEOUS CORONARY INTERVENTION UNDER OPTICAL COHERENCE TOMOGRAPHY GUIDANCE}

The concept of an IVUS guided PCI, including an absolute and relative stent expansion, stent apposition, edge dissection, and lesion coverage, has also been introduced in the DES era for stent optimization through the BMS era. In the Long-Term Health Outcome and Mortality Evaluation After Invasive Coronary Treatment using Drug Eluting Stents with or without the IVUS Guidance (HOME-DES IVUS) study, ${ }^{49)}$ an optimal stent deployment was defined as a complete apposition of the stent struts without any edge dissections, and an adequate stent expansion was defined as either a MSA of $>5.0 \mathrm{~mm}^{2}$ or $>90 \%$ of the distal reference lumen area. In the IVUS XPL study, an optimal stent expansion was defined as having an MLA of greater than the lumen area in the distal reference segments. ${ }^{48}$ With the development of the OCT system, the OCT criteria began to be based on the previous IVUS studies. In the Optical Coherence Tomography Guided Percutaneous Coronary Intervention With Nobori Stent Implantation in Patients With Non-ST-Segment-Elevation Myocardial Infarction (OCTACS) study, ${ }^{69)}$ the stent optimization criteria were: 1 ) MSA of $\geq 90 \%$ of the average reference lumen area; 2) avoiding any significant stent malapposition (defined as a strut that had detached $\leq 140 \mu \mathrm{m}$ from the underlying vessel wall); 3) no significant edge dissection (causing an MLA of $\geq 4.0 \mathrm{~mm}^{2}$ ); and 4) no significant residual stenosis (causing an MLA of $\geq 4.0 \mathrm{~mm}^{2}$ ). Prati F and colleagues reported the CLI-OPCI and CLI-OPCI II studies for evaluating the effect of OCT-guided PCI on the clinical outcomes. The criteria for stent optimization in the CLI-OPCI study were: 1 ) MSA of $\geq 90 \%$ of the average reference lumen area or $\geq 100 \%$ of the lumen area of the lowest reference lumen area; 2) distance of the stent to the lumen of $<200$ $\mu \mathrm{m}$; 3) edge dissection with a width of $<200 \mu \mathrm{m}$; 4) TP of $<200 \mu \mathrm{m}$; and 5) reference luminal narrowing of $\geq 4.0 \mathrm{~mm}^{2}$. Similarly, the CLI-OPCI II study suggested the following criteria: 


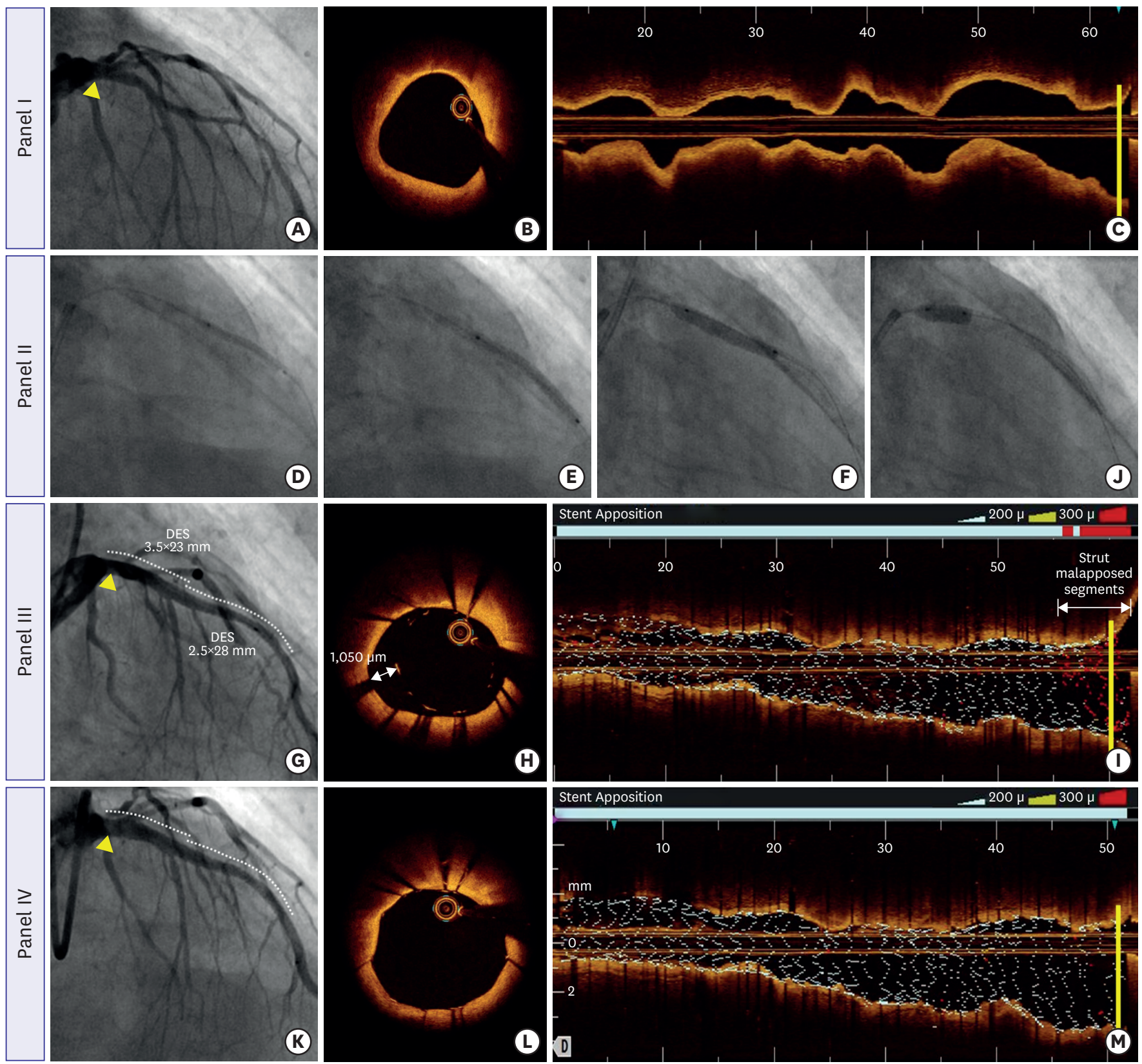

Figure 5. A representative case demonstrating a stent malapposition viewed by OCT. Preinterventional angiography and OCT images (panel I, A-C). Interventional images of pre-dilatation and stent implantation (panel II, D-F). Pre-dilatation was performed using a $2.5 \times 20 \mathrm{~mm}$ compliant balloon (D) followed by stent implantation in the LAD (1st DES $2.75 \times 28 \mathrm{~mm}$, 2nd DES $3.5 \times 23 \mathrm{~mm}$ ) (E-F). A post-PCl stent malapposition was detected by OCT images (panel III, G-I). Post- $\mathrm{PCl}$ angiography did not detect any stent malappositions (G). In the OCT cross-sectional view, the maximal stent to vessel wall distance was 1,050 $\mu \mathrm{m}$ (H). In the OCT longitudinal view, a critical stent malapposition (red line) was detected in the stent proximal segment and the stent malapposition length was approximately $5 \mathrm{~mm}(\mathrm{I})$. Additional high-pressure dilatation using a NC $4.5 \times 8 \mathrm{~mm}$ balloon (J). Final angiography and OCT images after the NC ballooning (panel IV, K-M). Slight expansion of the stent proximal segment on angiography (K). No evidence of a stent malapposition in the OCT cross-sectional view (L). No visible automatic detected critical stent malappositions in the OCT longitudinal view (M).

$\mathrm{OCT}=$ optical coherence tomography; $\mathrm{DES}=$ drug-eluting stent; $\mathrm{LAD}=$ left anterior descending; $\mathrm{NC}=$ noncompliant; $\mathrm{PCl}=$ percutaneous coronary intervention .

1) MSA of $\left.\geq 4.5 \mathrm{~mm}^{2} ; 2\right)$ MSA of $\geq 70 \%$ of the average reference lumen area; 3) stent-adjacent vessel lumen distance of $\leq 200 \mu \mathrm{m} ; 4)$ edge dissection with a width of $<200 \mu \mathrm{m}$ adjacent $(<5$ $\mathrm{mm}$ ) to a stent edge; 5 ) intrastent plaque/thrombus protrusion of $<500 \mu \mathrm{m}$ in thickness; and 6) reference luminal narrowing of $\geq 4.5 \mathrm{~mm}^{2}$. Of those, the MSA, distal edge dissection, and 
reference luminal narrowing were independent predictors of MACE. ${ }^{46(62)}$ Recently, two OCT randomized control trials have also reported stent optimization criteria. The OPINION trial ${ }^{38}$ suggested the following criteria: 1) MSA of $>90 \%$ of the average reference lumen area; 2) stent expansion defined by a MLD/maximum lumen diameter of $>0.7$; 3) a stent malapposition (distance between stent and lumen) of $\leq 350 \mu \mathrm{m}$ through the entire segments; 4) no flowlimiting protrusions; and 5) no flow-limiting edge dissections. The ILUMIEN III trial ${ }^{37}$ has proposed the following stent optimization criteria using OCT: 1) an acceptable stent expansion with MSA of $>90 \%$ in both the proximal and distal halves of the stent relative to the closest reference segment; 2 ) no tissue or thrombus protrusions with untreated reference segment disease; 3 ) no edge dissections that are $\geq 60^{\circ}$ of the circumference of the vessel at the site of the dissection, $\geq 3 \mathrm{~mm}$ in length, or any visible edge dissection of $<60^{\circ}$ of the circumference of the vessel of $<3 \mathrm{~mm}$ in length; and 4) stent apposition with struts clearly separated from the vessel wall by $<200 \mu \mathrm{m}$.

Overall, most studies have defined five important factors (stent expansion, stent apposition, TP, edge dissection, and lesion coverage) for stent optimization when using OCT. The acceptable criteria are summarized as shown in Figure $\mathbf{6}$. We also summarized the algorithm of the stent optimization under OCT guidance with a stepwise approach as shown in Figure 3 based on recent OCT studies. ${ }^{37(38) 46(62) 70)}$ During the pre-PCI OCT (Step 1), the stent size can be determined by the mean EEL diameter or mean lumen diameter based on the identification of the EEL contour in the reference segments while the stent length can be determined by the OCT measurements. If the lesion is heavily calcified, a lesion modification is needed. During the stent implantation (Step 2), the stent deployment is accompanied by a moderate

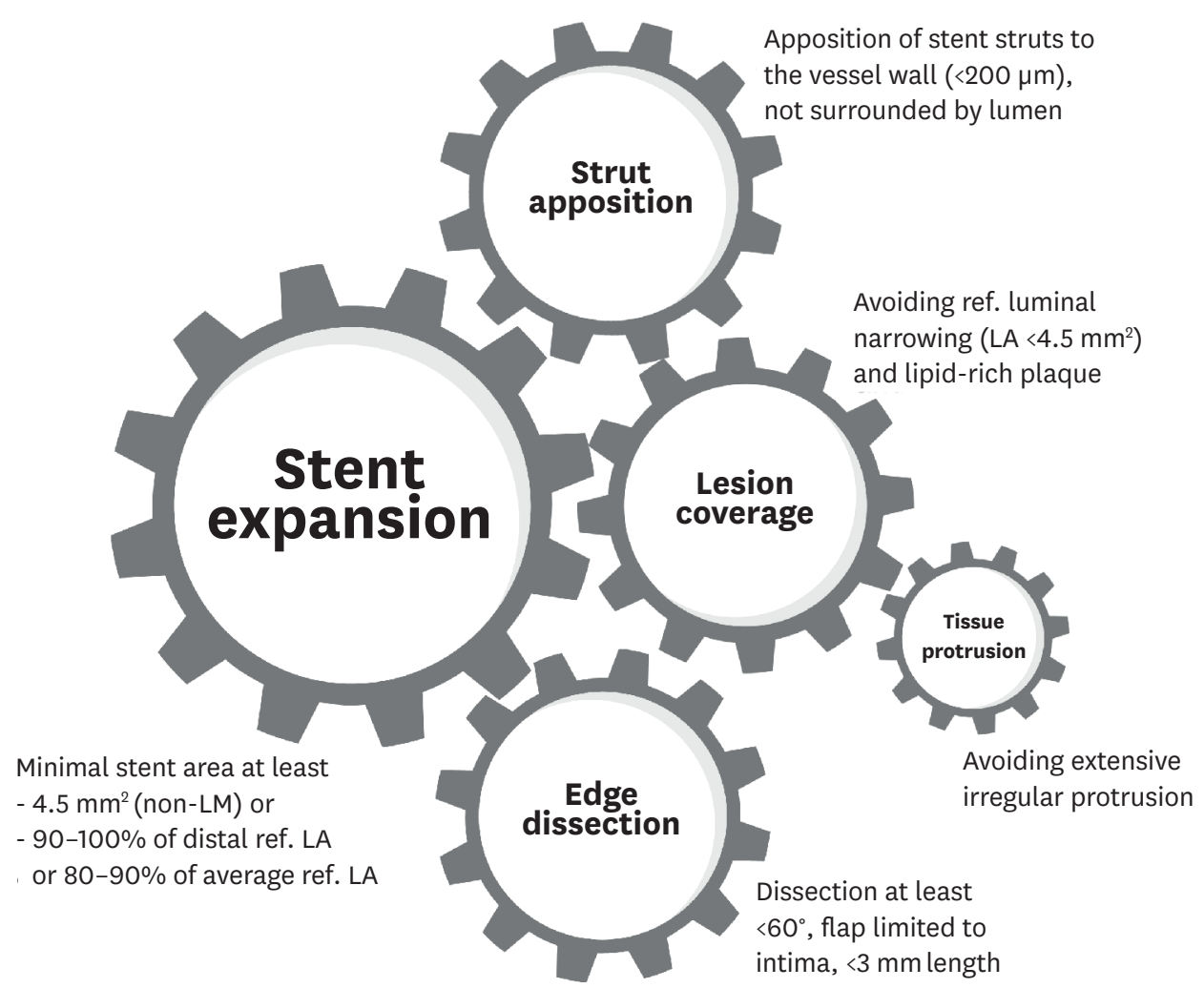

Figure 6. Acceptable criteria of stent optimization by OCT.

$\mathrm{LA}=$ lumen area; $\mathrm{LM}=$ left main; $\mathrm{OCT}$ = optical coherence tomography; ref. = reference. 
to high-pressure balloon inflation. After the stent implantation, residual stenosis within the stented segments should be evaluated by CAG. If residual stenosis exits, a post-dilatation using a non-compliant balloon should be performed. If there is no residual stenosis, a repeat OCT examination should be performed. During the post-PCI OCT (Step 4), at least the MSA, stent malapposition, edge dissection, lesion coverage, and TP should be evaluated and the following strategy can be decided according to the post-PCI OCT findings. An automated OCT-angiography co-registration system can be used to detect the landing zones of the stent edge and measure the optimal stent length. However, CAG has ambiguity as it visually selects "normal-appearing" reference segments in which lipid-rich plaque may be extensive. ${ }^{16)}$ Future studies are required to compare the anatomic lesion length by OCT with the physiologic lesion length measured by a FFR pull-back or using automated instantaneous wave-free ratio maps $^{71)}$ in tandem or with diffuse stenosis to investigate the effect of using both OCT imaging and physiologic guidance in the stent optimization of such lesions. An OCT-angiography co-registration system can be used for a quick detection and targeted post-dilatation of underexpanded stent segments without any unnecessary post-dilatation, especially near the proximal and distal stent edges where post-dilatation might lead to an edge complication. ${ }^{22}$

\section{IMAGING OUTCOMES OF THE OPTICAL COHERENCE TOMOGRAPHY-GUIDED PERCUTANEOUS CORONARY INTERVENTION}

Any change within stented segments can be clearly evaluated through repeated OCT examinations after PCI. Many studies have reported the imaging outcome after stent implantations immediately and at follow-up using OCT examinations (Table 3)..$^{37455(69) 73-76)}$ Two OCT studies have addressed the imaging outcomes between the OCT-guided PCI and angio-guided PCI. The DETErmination of the Duration of the Dual Antiplatelet Therapy by the Degree of the Coverage of The Struts on Optical Coherence Tomography (DETECT-OCT) trial $^{73)}$ reported that the stent and lumen volume index in the OCT-guided PCI group at the 3 -month follow-up are larger than those of the angio-guided PCI group $\left(7.9 \pm 2.4 \mathrm{~mm}^{3} \mathrm{vs}\right.$. $7.2 \pm 2.2 \mathrm{~mm}^{3}, \mathrm{p}<0.001$ and $7.4 \pm 2.3 \mathrm{~mm}^{3}$ vs. $6.8 \pm 2.2 \mathrm{~mm}^{3}, \mathrm{p}=0.001$, respectively). In addition, the maximal axial length of a malapposed strut and percent of uncovered struts in the OCT-guided group were lower than those in the angio-guided group $(0.2 \mathrm{~mm}$ vs. $1.0 \mathrm{~mm}$, $\mathrm{p}=0.021$ and $7.5 \%$ vs. $9.9 \%, \mathrm{p}=0.009$, respectively). In the OCTACS trial, $\left.{ }^{69}\right)$ the MSA and stent malapposition did not significantly differ between the OCT-guided and angio-guided PCI groups ( $6.2 \pm 1.6$ vs. $5.7 \pm 1.9, \mathrm{p}=0.21$ and $48.4 \%$ vs. $51.6 \%$, $\mathrm{p}=0.85$, respectively). However, the percentage of uncovered struts was significant lower in the OCT-guided group than angioguided group ( $4.3 \%$ vs. $9.0 \%, \mathrm{p}<0.01)$. On the other hand, several studies have addressed the imaging outcomes between the OCT versus IVUS imaging modalities. Habara et al. ${ }^{74}$ reported that the MSA is smaller $(6.1 \pm 2.2 \mathrm{~mm}$ vs. $7.1 \pm 2.1 \mathrm{~mm}, \mathrm{p}<0.05)$ and the frequency of a significant residual reference segment stenosis at the proximal edge is higher in the OCT-guided group $(\mathrm{p}<0.05)$ than IVUS-guided group. However, the malappositions were similar $(\mathrm{p}=0.34)$ between the two groups. The OPINION-imaging substudy ${ }^{76}$ showed that immediately after the PCI, the OCT-guided PCI group had a smaller trend of the MSA (5.28 $\mathrm{mm}^{2}$ vs. $6.12 \mathrm{~mm}^{2}, \mathrm{p}=0.088$ ), fewer proximal stent-edge hematomas ( $\mathrm{p}=0.04$ ), and fewer irregular protrusions ( $\mathrm{p}=0.014$ ) than the IVUS-guided PCI group. The MLA, edge dissections, and malappositions were comparable between the two groups. The ILUMIEN II study ${ }^{75}$ reported the results of the final post-PCI stent expansion according to the type of imaging 
Table 3. Comparison of the OCT studies for the imaging outcome

\begin{tabular}{|c|c|c|c|c|c|c|c|c|c|c|c|c|c|c|}
\hline \multirow{2}{*}{$\begin{array}{l}\text { Study/first } \\
\text { author, year }\end{array}$} & \multirow{2}{*}{ Design } & \multicolumn{3}{|c|}{ Number } & \multirow{2}{*}{ Endpoint } & \multicolumn{4}{|c|}{ MSA $\left(\mathrm{mm}^{2}\right)$} & \multicolumn{4}{|c|}{ Stent expansion (\%) } & \multirow{2}{*}{ Results } \\
\hline & & OCT & Angio & IVUS & & OCT & Angio & IVUS & $p$ & OCT & Angio & IVUS & $p$ & \\
\hline $\begin{array}{l}\text { OCTACS, } \\
2015^{69)}\end{array}$ & RCT & 40 & 45 & - & $\begin{array}{l}\text { Percent of } \\
\text { uncovered } \\
\text { struts }\end{array}$ & $\begin{array}{c}\text { Post-PCl; } \\
6.2 \pm 1.6\end{array}$ & $\begin{array}{c}\text { Post-PCl; } \\
5.7 \pm 1.9\end{array}$ & - & 0.21 & - & - & - & - & $\begin{array}{l}\text { 6-month uncovered } \\
\text { struts }(\mathrm{OCT} ; 4.3 \% \text { vs. } \\
\text { angio; } 9.0 \%, \mathrm{p}<0.01)\end{array}$ \\
\hline $\begin{array}{l}\text { DOCTORS, } \\
2016^{45)}\end{array}$ & $\mathrm{RCT}$ & 120 & 120 & - & $\begin{array}{l}\text { Post } \\
\text { PCl-FFR }\end{array}$ & \multicolumn{4}{|c|}{$\begin{array}{c}\text { MLA }\left(\mathrm{mm}^{2}\right): 6.0 \pm 2.1 \text { (immediately PS OCT) } \\
\text { vs. } 6.4 \pm 2.0 \text { (post OCT optimization), } \\
\text { p }<0.001\end{array}$} & \multicolumn{4}{|c|}{$\begin{array}{c}78.9 \pm 12.4 \% \text { (immediately PS OCT) } \\
\text { vs. } 84.1 \pm 7.3 \% \text { (post OCT optimization), } \\
\text { p }<0.001\end{array}$} & $\begin{array}{l}\text { Post-PCI FFR (OCT; } \\
0.94 \pm 0.04 \text { vs. angio; } \\
0.92 \pm 0.05, p=0.005)\end{array}$ \\
\hline $\begin{array}{l}\text { DETECT-OCT, } \\
2018^{73)}\end{array}$ & RCT & 445 & 449 & - & $\begin{array}{l}\text { The } \\
\text { difference } \\
\text { in the } \\
\text { early strut } \\
\text { coverage }\end{array}$ & $6.4 \pm 2.0$ & - & - & - & - & - & - & - & $\begin{array}{l}\text { The stent volume index } \\
\text { at the } 3 \text {-month follow- } \\
\text { up OCT was larger than } \\
\text { that with angiography } \\
\text { guidance }(7.9 \pm 2.4 \\
\text { vs. } 7.2 \pm 2.2 \mathrm{~mm}^{3} / \mathrm{mm} \text {, } \\
\text { p }<0.001)\end{array}$ \\
\hline \multirow[t]{2}{*}{$\begin{array}{l}\text { Habara et al., } \\
2012^{74)}\end{array}$} & $\mathrm{RCT}$ & 35 & - & 35 & $\begin{array}{l}\text { Stent } \\
\text { expansion } \\
\text { by IVUS } \\
\text { (post-PCI) }\end{array}$ & $6.1 \pm 2.2$ & - & $7.1 \pm 2.1$ & 0.04 & $84.2 \pm 15.8$ & - & $98.8 \pm 16.5$ & 0.003 & \multirow{2}{*}{$\begin{array}{l}\text { OCT guidance was } \\
\text { associated with a } \\
\text { smaller stent expansion } \\
\text { and more residual } \\
\text { stenosis compared with } \\
\text { IVUS guidance }\end{array}$} \\
\hline & & & & & $\begin{array}{l}\text { Stent } \\
\text { expansion } \\
\text { by OCT } \\
\text { (post-PCI) }\end{array}$ & $5.7 \pm 2.1$ & - & $6.9 \pm 2.4$ & 0.03 & - & - & - & - & \\
\hline $\begin{array}{l}\text { ILUMIEN II, } \\
2015^{75)}\end{array}$ & $\begin{array}{l}\text { Post-hoc } \\
\text { analysis }\end{array}$ & 354 & - & 586 & $\begin{array}{l}\text { Final post- } \\
\mathrm{PCl} \text { stent } \\
\text { expansion }\end{array}$ & $5.0(3.9-6.4)$ & - & $5.5(4.4-7.0)$ & $<0.001$ & $\begin{array}{c}72.8 \\
(63.3-81.3)\end{array}$ & - & $\begin{array}{c}70.6 \\
(62.3-78.8)\end{array}$ & 0.29 & $\begin{array}{l}\text { OCT and IVUS } \\
\text { guidance resulted in a } \\
\text { comparable degree of } \\
\text { stent expansion }\end{array}$ \\
\hline \multirow[t]{2}{*}{$\begin{array}{l}\text { OPINION- } \\
\text { imaging } \\
\text { substudy, } \\
2018^{76)}\end{array}$} & \multirow[t]{2}{*}{$\begin{array}{l}\text { RCT-sub } \\
\text { study }\end{array}$} & 54 & - & 49 & $\begin{array}{l}\text { MSA by OCT } \\
\text { post-PCl }\end{array}$ & $\begin{array}{c}5.17 \\
(4.06-6.29)\end{array}$ & - & $\begin{array}{c}5.63 \\
(4.76-7.52)\end{array}$ & 0.088 & $\begin{array}{c}\text { Stent } \\
\text { expansion } \\
\text { index; } 0.82 \\
(0.71-0.94)\end{array}$ & - & $\begin{array}{c}\text { Stent } \\
\text { expansion } \\
\text { index; } 0.89 \\
(0.81-0.99)\end{array}$ & 0.17 & \multirow{2}{*}{$\begin{array}{l}\text { The MLA at the } \\
\text { 8-month follow-up was } \\
\text { comparable, and OCT } \\
\text { and IVUS guidance are } \\
\text { similarly feasible using } \\
\text { the current DES stents }\end{array}$} \\
\hline & & & & & $\begin{array}{l}\text { MLA at } \\
\text { 8-month } \\
\text { follow-up } \\
\text { OCT }\end{array}$ & $\begin{array}{c}4.81 \\
(3.26-5.92)\end{array}$ & - & $\begin{array}{c}5.04 \\
(4.43-6.24)\end{array}$ & 0.18 & - & - & - & - & \\
\hline $\begin{array}{l}\text { ILUMIEN III; } \\
\text { OPTIMIZE PCI, } \\
2016^{37)}\end{array}$ & RCT & 140 & 135 & 140 & $\begin{array}{l}\text { Post-PCl } \\
\text { MSA by OCT } \\
\text { (efficacy) }\end{array}$ & $\begin{array}{c}5.79 \\
(4.54-7.34)\end{array}$ & $\begin{array}{c}5.49 \\
(4.39-6.59)\end{array}$ & $\begin{array}{c}5.89 \\
(4.67-7.80)\end{array}$ & $\begin{array}{l}\text { OCT vs. } \\
\text { IVUS; } \\
0.42 \\
\text { OCT vs. } \\
\text { Angio; } \\
0.12\end{array}$ & 87.6 & 82.9 & 86.5 & $\begin{array}{l}\text { OCT vs. } \\
\text { IVUS; } \\
\text { O.77 } \\
\text { OCT vs. } \\
\text { Angio; } \\
0.02\end{array}$ & $\begin{array}{l}\text { OCT guidance resulted } \\
\text { in a similar MSA to that } \\
\text { of IVUS guidance }\end{array}$ \\
\hline
\end{tabular}

DES = drug-eluting stent; DETECT-OCT = DETErmination of the Duration of the Dual Antiplatelet Therapy by the Degree of the Coverage of The Struts on Optical Coherence Tomography; DOCTORS = Does Optical Coherence Tomography Optimize Results of Stenting; FFR = fractional flow reserve; IVUS = intravascular ultrasound; MLA = minimal lumen area; MSA = minimal stent area; OCT = optical coherence tomography; OCTACS = Optical Coherence Tomography Guided Percutaneous Coronary Intervention With Nobori Stent Implantation in Patients With Non-ST-Segment-Elevation Myocardial Infarction; PCI = percutaneous coronary intervention; PS = polarization sensitive; $\mathrm{RCT}$ = randomized controlled trial.

guidance. After a matched-pair analysis, the degree of stent expansion did not significantly differ between the OCT and IVUS guidance groups $(72.8 \%$ vs. $70.6 \%$, $\mathrm{p}=0.29)$. Although the incidences of any stent malapposition, any TP, and any edge dissection after PCI were higher in the OCT guidance group, major malapposition, major TP, and major dissection were similar between the OCT and IVUS guidance groups. The ILUMIEN III trial ${ }^{37)}$ showed a post-PCI MSA according to three imaging modalities. The MSA did not significantly different among the 3 groups and the minimum and mean stent expansion rates did not differ between the OCT-guided and IVUS-guided groups ( $87.6 \%$ vs. $86.5 \%$, $p=0.77$ and $105.8 \%$ vs. $106.3 \%$, $\mathrm{p}=0.63$, respectively). However, the minimum and mean stent expansion rates were higher in the OCT-guided PCI group than angio-guided PCI group $(87.6 \%$ vs. $82.9 \%$, $\mathrm{p}=0.02$ and $105.8 \%$ vs. $101.4 \%, \mathrm{p}=0.001$, respectively) and the major dissection and major malapposition rates were lower in the OCT-guided PCI group than IVUS-guided PCI group (14\% vs. $26 \%$, $\mathrm{p}=0.009$ and $11 \%$ vs. $21 \%, \mathrm{p}=0.02$, respectively). 
According to the imaging outcomes of the OCT studies, the OCT-guided PCI had an equal or larger MSA stent expansion and better strut coverage at the follow-up as compared to the angio-guided PCI. ${ }^{69733}$ In contrast, the OCT-guided PCI had a smaller or equal MSA with a lower or similar incidence of major dissections and major malappositions as compared to the IVUS guided PCI.

\section{OPTICAL COHERENCE TOMOGRAPHY-GUIDED PERCUTANEOUS CORONARY INTERVENTION AND THE FRACTIONAL FLOW RESERVE}

The relationship between the OCT-guided PCI and FFR has been evaluated in a few studies. In the DOCTORS study, ${ }^{45}$ post-PCI OCT revealed that $42 \%$ of the patients had stent underexpansions and $32 \%$ of patients had stent malappositions, leading to a more frequent use of post-stent high-pressure dilatation in the OCT-guided PCI than angio-guided PCI ( $43 \%$ vs. $12.5 \%, \mathrm{p}<0.001)$. Consequently, the OCT-guided group had a significantly higher FFR value than the anigo-guided group $(0.94 \pm 0.04$ vs. $0.92 \pm 0.05, \mathrm{p}=0.005)$. ILUMIEN I study, ${ }^{77)}$ and in contrast, the post-PCI OCT imaging revealed $14.5 \%$ rate of stent malappositions, $7.6 \%$ rate of stent underexpansions, and $2.7 \%$ rate of edge dissections. Regardless of the OCT optimization sequences, the final FFR values did not show any significant differences. These observations suggested that the effect of the OCT-guided PCI on the final FFR value is not clear yet.

\section{CLINICAL OUTCOMES OF THE OPTICAL COHERENCE TOMOGRAPHY-GUIDED PERCUTANEOUS CORONARY INTERVENTION}

Several OCT studies have addressed the clinical outcomes of the OCT-guided versus IVUSguided PCI or OCT-guided versus IVUS-guided versus angio-guided PCI (Table 4). The ILUMIEN I ${ }^{77}$ study reported that OCT-guided PCI (single arm) had a low MACE rate at 30 days (death, $0.25 \%$; repeat PCI, $1.7 \%$; and stent thrombosis, $0.25 \%$ ). In a retrospective analysis of 670 patients in the CLI-OPCI study, ${ }^{(2)}$ OCT-guided PCI was associated with improved outcomes compared to angio-guided PCI. In addition, a suboptimal OCT stent deployment was confirmed as an independent predictor of MACE at 12-months of follow-up (HR, 3.53; 95\% confidence interval [CI], 2.2-5.8; $\mathrm{p}<0.001)$ in the CLI-OPCI II study. ${ }^{46)}$ In the Pan-London PCI registry, ${ }^{78)}$ a large national observation registry, the mortality of patients who underwent OCT-guidance was 7.7\%, which was significantly lower than that of patients with either IVUSguidance $(12.2 \%)$ or angiography-guidance $(15.7 \%$; $p<0.001)$. It was also significantly different from that of the patients in the elective $(\mathrm{p}<0.001)$ or emergent subgroup $(\mathrm{p}=0.002)$. Moreover, this difference remained significant after an adjustment (HR, 0.48; 95\% CI, 0.26-0.81; $\mathrm{p}=0.001$ ) and propensity score matching (HR, 0.39; 95\% CI, 0.21-0.77; $\mathrm{p}<0.001$; OCT vs. angiography-guidance). On the contrary, a total of 285 patients in the OCT-guided group and 1,547 patients in the angio-guided group were enrolled in the FORMIDABLE-CARDIOGROUP IV and USZ Registry ${ }^{79}$ resulting in 270 patients for each cohort after propensity score matching. After a follow-up of 700 days, there was no significant difference in the risk of an MI, target vessel revascularization, or stent thrombosis between the two groups. In the 
Table 4. Comparison of the OCT studies for the clinical outcome

\begin{tabular}{|c|c|c|c|c|c|c|c|c|c|c|c|c|}
\hline \multirow{2}{*}{$\begin{array}{l}\text { Study/first } \\
\text { author, year }\end{array}$} & \multirow{2}{*}{ Design } & \multicolumn{3}{|c|}{ Number } & \multirow{2}{*}{$\begin{array}{l}\text { Duration } \\
\text { (months) }\end{array}$} & \multirow{2}{*}{ Endpoint } & \multicolumn{5}{|c|}{ MACE } & \multirow{2}{*}{ Key findings } \\
\hline & & OCT & Angio & IVUS & & & Cardiac death & $\mathrm{MI}$ & TLR & TVR & ST & \\
\hline $\begin{array}{l}\text { CLI-OPCI, } \\
2012^{62)}\end{array}$ & $\begin{array}{l}\text { Matched } \\
\text { patients }\end{array}$ & 335 & 335 & - & 12 & $\mathrm{CD}$ or $\mathrm{MI}$ & $\begin{array}{c}\text { OCT; } 1.2 \% \text { vs. } \\
\text { Angio; } 4.5 \% \\
(p=0.010) \\
(1 y e a r C D)\end{array}$ & $\begin{array}{l}\text { OCT; } 5.4 \% \text { vs. } \\
\text { Angio; } 8.7 \% \\
(p=0.096) \\
(C D \text { or } M I)\end{array}$ & $\begin{array}{l}\text { Composite of } \\
\text { CD, MI or RR; } \\
9.6 \% \text { vs. } 13.0 \% \\
\quad(p=0.006)\end{array}$ & - & - & $\begin{array}{l}\text { OCT guidance was } \\
\text { associated with a } \\
\text { significantly lower } \\
\text { rate of clinical } \\
\text { events at 1-year }\end{array}$ \\
\hline $\begin{array}{l}\text { OPNION, } \\
2016^{38)}\end{array}$ & $\mathrm{RCT}$ & 412 & - & 405 & 12 & $\begin{array}{l}\text { TVF } \\
\text { (composite } \\
\text { of CD, target- } \\
\text { vessel MI, } \\
\text { ischemia- } \\
\text { driven TVR) }\end{array}$ & $\begin{array}{c}\text { OCT; } 0.0 \% \text { vs. } \\
\text { IVUS; } 0.2 \% \\
\quad(p=0.99)\end{array}$ & $\begin{array}{l}\text { OCT; } 0.5 \% \text { vs. } \\
\text { IVUS; } 0.7 \% \\
\quad(p=0.98)\end{array}$ & $\begin{array}{c}\text { OCT; } 2.7 \% \text { vs. } \\
\text { IVUS; } 3.0 \% \\
\quad(p=0.97)\end{array}$ & $\begin{array}{c}\text { OCT; } 4.9 \% \text { vs. } \\
\text { IVUS; } 4.2 \% \\
\quad(p=0.78)\end{array}$ & $\begin{array}{c}\text { OCT; } 0.2 \% \text { vs. } \\
\text { IVUS; } 0.5 \% \\
\quad(p=0.99)\end{array}$ & $\begin{array}{l}\text { OCT guidance was } \\
\text { non-inferior to IVUS } \\
\text { guidance regarding } \\
\text { the clinical outcome } \\
\text { at 1-year }\end{array}$ \\
\hline $\begin{array}{l}\text { ILUMIEN III; } \\
\text { OPTIMIZE PCI, } \\
2016^{37)}\end{array}$ & $\mathrm{RCT}$ & 158 & 143 & 140 & 1 & $\begin{array}{l}\text { Post-PCl } \\
\text { MSA by OCT } \\
\text { (efficacy) } \\
\text { Procedureal } \\
\text { MACE } \\
\text { (safety) }\end{array}$ & $\begin{array}{l}\begin{array}{c}\text { All cause } \\
\text { death }\end{array} \\
\text { OCT; } 0.0 \% \text { vs. } \\
\text { IVUS; } 0.0 \% \text { vs. } \\
\text { Angio; } 0.0 \%\end{array}$ & $\begin{array}{l}\text { Target vessel } \\
\text { MI } \\
\text { OCT; } 1.0 \% \text { vs. } \\
\text { IVUS; } 1.0 \% \text { vs. } \\
\text { Angio; } 0.0 \%\end{array}$ & $\begin{array}{l}\text { ID-TLR } \\
\text { OCT; } 1.0 \% \text { vs. } \\
\text { IVUS; } 0.0 \% \text { vs. } \\
\text { Angio; } 1.0 \%\end{array}$ & - & $\begin{array}{l}\text { OCT; } 1.0 \% \text { vs. } \\
\text { IVUS; } 0.0 \% \text { vs. } \\
\text { Angio; } 0.0 \%\end{array}$ & $\begin{array}{l}\text { OCT guidance was } \\
\text { safe and resulted in } \\
\text { a similar MSA to that } \\
\text { of IVUS guidance }\end{array}$ \\
\hline $\begin{array}{l}\text { FORMIDABLE- } \\
\text { CARDIOGROUP } \\
\text { IV and USZ } \\
\text { Registry, } 2017^{79)}\end{array}$ & PSM analysis & 270 & 270 & - & 24 & $\begin{array}{l}\text { Number of } \\
\text { stent used } \\
\text { (primary), } \\
\text { MACE } \\
\text { (secondary) }\end{array}$ & $\begin{array}{l}\text { All cause death } \\
\text { OCT; } 3.0 \% \text { vs. } \\
\text { Angio; } 4.0 \% \\
\quad(p=0.15)\end{array}$ & $\begin{array}{c}\text { OCT; } 6.0 \% \text { vs. } \\
\text { Angio; } 6.0 \% \\
\quad(p=0.86)\end{array}$ & $\begin{array}{l}\text { OCT; } 2.0 \% \text { vs. } \\
\text { Angio; } 3.0 \% \\
\quad(p=0.92)\end{array}$ & $\begin{array}{c}\text { OCT; } 2.0 \% \text { vs. } \\
\text { Angio; } 4.0 \% \\
\quad(p=0.15)\end{array}$ & $\begin{array}{c}\text { OCT; } 0.0 \% \text { vs. } \\
\text { Angio; } 2.7 \% \\
\quad(p=0.26)\end{array}$ & $\begin{array}{l}\text { OCT guidance } \\
\text { reduced the } \\
\text { number of stents } \\
\text { used, but there } \\
\text { was no statistically } \\
\text { significant difference } \\
\text { in the clinical } \\
\text { outcomes }\end{array}$ \\
\hline $\begin{array}{l}\text { DETECT-OCT, } \\
2018^{73)}\end{array}$ & $\mathrm{RCT}$ & 320 & 459 & - & 3 & $\begin{array}{l}\text { The } \\
\text { difference in } \\
\text { early strut } \\
\text { coverage }\end{array}$ & $\begin{array}{c}\text { 3-month DAPT; } \\
0.0 \% \text { vs. } \\
\text { 12-month DAPT; } \\
0.0 \%(p=N A)\end{array}$ & $\begin{array}{c}\text { 3-month DAPT; } \\
0.3 \% \text { vs. } \\
\text { 12-month DAPT; } \\
0.0 \%(p=0.41)\end{array}$ & - & $\begin{array}{c}\text { 3-month } \\
\text { DAPT; } 0.6 \% \\
\text { vs. } 12 \text {-month } \\
\text { DAPT; } 0.4 \% \\
\quad(p=0.72)\end{array}$ & $\begin{array}{c}\text { 3-month DAPT; } \\
0.3 \% \text { vs. } \\
\text { 12-month DAPT; } \\
0.0 \%(p=0.41)\end{array}$ & $\begin{array}{l}\text { OCT guidance } \\
\text { reduced the percent } \\
\text { of uncovered and } \\
\text { malapposed struts. } \\
\text { Short-term DAPT } \\
\text { may be feasible in } \\
\text { selected patients } \\
\text { with a favorable } \\
\text { early strut coverage }\end{array}$ \\
\hline $\begin{array}{l}\text { Pan-London } \\
\mathrm{PCl}, 2018^{78)}\end{array}$ & $\begin{array}{l}\text { Observational } \\
\text { cohort }\end{array}$ & 1,149 & 75,046 & 10,971 & $\begin{array}{c}58 \\
\text { (median) }\end{array}$ & $\begin{array}{l}\text { All causes } \\
\text { of mortality }\end{array}$ & $\begin{array}{l}\text { All cause death } \\
\text { OCT; } 0.3 \% \text { vs. } \\
\text { IVUS; } 0.4 \% \text { vs. } \\
\text { Angio; } 0.7 \% \\
\quad(p=0.010)\end{array}$ & $\begin{array}{l}\text { Q wave-MI } \\
\text { OCT; } 0.2 \% \text { vs. } \\
\text { IVUS; } 0.5 \% \text { vs. } \\
\text { Angio; } 0.7 \% \\
(p=0.046)\end{array}$ & - & - & - & $\begin{array}{l}\text { OCT guidance was } \\
\text { associated with an } \\
\text { improved clinical } \\
\text { outcome }\end{array}$ \\
\hline
\end{tabular}

$\mathrm{CD}=$ cardiac death; $\mathrm{CLI}-\mathrm{OPCl}=$ Centro per la Lotta Contro L'Infarto-Optimization of Percutaneous Coronary Intervention; DAPT = dual antiplatelet therapy; DETECT-OCT = DETErmination of the Duration of the Dual Antiplatelet Therapy by the Degree of the Coverage of The Struts on Optical Coherence Tomography; ILUMIEN = Observational Study of Optical Coherence Tomography in Patients Undergoing Fractional Flow Reserve and Percutaneous Coronary Intervention; IVUS = intravascular ultrasound; $\mathrm{MACE}=$ major adverse cardiovascular event; $\mathrm{MI}=$ myocardial infarction; $\mathrm{MSA}=$ minimal stent area; OCT = optical coherence tomography; OPINION = Optical Frequency Domain Imaging vs. Intravascular Ultrasound in Percutaneous Coronary Intervention; PCI = percutaneous coronary intervention; PSM = propensity-score matching; $\mathrm{RCT}=$ randomized control trial; $\mathrm{RR}=$ repeat revascularization; $\mathrm{ST}=\mathrm{stent}$ thrombosis; $\mathrm{TLR}=\mathrm{target}$ lesion revascularization; TVF = target vessel failure; TVR = target vessel revascularization .

OPINION trial, target vessel failures occurred in 5.2\% of 401 patients undergoing an OCTguided PCI and in $4.9 \%$ of 390 patients undergoing an IVUS-guided PCI, demonstrating the non-inferiority of the OCT-guided PCI to the IVUS-guided PCI over 1 year (HR, 1.07; the upper limit of one-sided $\left.95 \% \mathrm{CI}, 1.80 ; \mathrm{P}_{\text {non-nferiority }}=0.042\right) .{ }^{38776)}$ Our retrospective study also reported a one-year cumulative incidence of MACE in those who underwent a second-generation DES implantation under OCT (122 patients) or IVUS (168 patients) guidance. In adjusted comparisons between the OCT-guided and IVUS-guided PCI groups, there was no significant difference in the rate of MACE or ST at 1-year follow-up. ${ }^{80)}$ In the ILUMIEN III ${ }^{37)}$ trial, the procedural MACE rate did not significantly differ among these three groups: four (3\%) of 158 patients in the OCT-guided group, one (1\%) of 146 in the IVUS-guided group, and one (1\%) of 146 in the angio-guided group (OCT vs. IVUS, $\mathrm{p}=0.37$; OCT vs. angiography, $\mathrm{p}=0.37$ ). Taken together, the OCT-guided PCI was at least non-inferior or superior to the angio-guided PCI and non-inferior to the IVUS-guided PCI in terms of the mid-term clinical outcomes. 


\section{LIMITATIONS OF OPTICAL COHERENCE TOMOGRAPHY}

The current OCT technology has several limitations. Since its penetration power (1 to $2 \mathrm{~mm}$ ) has a lower depth than IVUS ( 8 to $10 \mathrm{~mm}$ ), the plaque volume and morphology of plaques in the deep layers of the vessel wall might be invisible by OCT. In addition, it might be difficult to differentiate calcifications from lipid-rich lesions, especially when there is a large plaque burden. As noted above, under certain circumstances, signal attenuation by lipidic plaques can lead to an ambiguous EEL and preclude the EEL-based stent sizing. In addition, the analysis of the structures below a red thrombus is limited by a high signal attenuation that can cast a shadow on the vessel wall. To make the correct interpretation of the OCT images, several types of artifact due to the light propagation, OCT catheter location and movement, and artifact associated with stents need to be considered ${ }^{81}$ In the case of renal dysfunction, contrast should be used discreetly. Although dextran can be used in OCT as an alternative flush material, it is not recommended for patients with chronic renal insufficiency. ${ }^{82}$ Lastly, two-dimensional OCT imaging has limitations, particularly for bifurcation lesions during the PCI and for evaluating stent deformations and fractures. To mitigate these limitations, a three-dimensional analysis is promising. ${ }^{8384)}$

\section{UPCOMING STUDIES}

Although the concept of OCT-guided PCI has been well established, data on its clinical impact are still lacking. Compared to angio-guided PCI or IVUS-guided PCI, a few studies have shown a positive signal in OCT-guided PCI, but not other studies. Therefore, further investigation is inevitable to evaluate whether the OCT-guided PCI can improve the clinical outcomes, especially for complex lesions. Recently, two Korean studies on OCT-guided PCI are ongoing to evaluate their clinical effects. The Optical CoherenCe Tomography-gUided Coronary Intervention in Patients With Complex lesIons (OCCUPI) trial is a prospective, multicenter, randomized study to prove the superiority of OCT-guided PCI for the clinical outcome as compared to angio-guided PCI for complex lesions. The Optical Coherence Tomography Versus Intravascular Ultrasound Guided Percutaneous Coronary Intervention (OCTIVUS) trial (NCT03394079) is a prospective, open-label, multicenter, dual arm, and randomized trial to establish that OCT-guided PCI is non-inferior to IVUS-guided PCI regarding target vessel failures at 1 year. On the other hand, the ILUMIEN IV trial (NCT03507777) is a prospective, multinational, multicenter, superiority designed, singleblind clinical trial that randomizes subjects to OCT-guided versus angio-guided coronary stent implantations with high-risk clinical characteristics and/or with high-risk angiographic lesions. The objective of this clinical trial is to demonstrate that OCT-guided PCI can achieve larger post-PCI lumen dimensions and improve the clinical cardiovascular outcomes. The results of these studies are expected to reveal the effect of IVUS and OCT on the clinical outcome of contemporary DES implantations in an environment close to the real world of an elective PCI.

\section{CONCLUSIONS}

With the technical development of OCT systems, the use of OCT during PCI has been rapidly increasing in daily practice. Similar to IVUS, OCT provides quantitative and qualitative information on the inside of the vessel wall before the PCI as well as the stent optimization 
after the PCI. The ILUMIEN I trial reported that pre-PCI OCT contributed to a change in the treatment strategy in $57 \%$ of cases and post-PCI OCT drove further stent optimization in $27 \%$ of cases, ${ }^{77)}$ suggesting that OCT already had a position as a user-friendly decision-making tool during stent implantations. Furthermore, any efforts for OCT-guided PCI may have long-term clinical benefits after stent implantations. Because the previous IVUS studies demonstrated that although half of the patients in the IVUS-guided PCI group failed to achieve stent optimization, they still had improved clinical events during the follow-up period as compare to the angio-guided PCI group. ${ }^{48}$ Therefore, in order to obtain clinical benefits from an OCTguided PCI, a precise stepwise approach before and after the PCI is needed and the physician must know when and how to use the OCT in their practice.

\section{ACKNOWLEDGEMENTS}

We thank Dr. Yun-Kyeong Cho, Dr. Hyuck-Jun Yoon, and Dr. Chang-Wook Nam for their comments that greatly improved the manuscript and Mr. John Martin for his linguistic assistance.

\section{REFERENCES}

1. Katagiri Y, De Maria GL, Kogame N, et al. Impact of post-procedural minimal stent area on 2-year clinical outcomes in the SYNTAX II trial. Catheter Cardiovasc Interv 2019;93:E225-34. PUBMED | CROSSREF

2. Song HG, Kang SJ, Ahn JM, et al. Intravascular ultrasound assessment of optimal stent area to prevent in-stent restenosis after zotarolimus-, everolimus-, and sirolimus-eluting stent implantation. Catheter Cardiovasc Interv 2014;83:873-8. PUBMED | CROSSREF

3. Authors/Task Force membersWindecker S, Kolh P, et al. 2014 ESC/EACTS Guidelines on myocardial revascularization: The Task Force on Myocardial Revascularization of the European Society of Cardiology (ESC) and the European Association for Cardio-Thoracic Surgery (EACTS)Developed with the special contribution of the European Association of Percutaneous Cardiovascular Interventions (EAPCI). Eur Heart J 2014;35:2541-619. PUBMED | CROSSREF

4. Levine GN, Bates ER, Blankenship JC, et al. 2011 ACCF/AHA/SCAI Guideline for percutaneous coronary intervention. A report of the American College of Cardiology Foundation/American Heart Association Task Force on Practice Guidelines and the Society for Cardiovascular Angiography and Interventions. J Am Coll Cardiol 2011;58:e44-122.

PUBMED | CROSSREF

5. Jang JS, Song YJ, Kang W, et al. Intravascular ultrasound-guided implantation of drug-eluting stents to improve outcome: a meta-analysis. JACC Cardiovasc Interv 2014;7:233-43. PUBMED | CROSSREF

6. Bavishi C, Sardar P, Chatterjee S, et al. Intravascular ultrasound-guided vs angiography-guided drugeluting stent implantation in complex coronary lesions: meta-analysis of randomized trials. Am Heart J 2017;185:26-34. PUBMED | CROSSREF

7. Neumann FJ, Sousa-Uva M, Ahlsson A, et al. 2018 ESC/EACTS Guidelines on myocardial revascularization. Eur Heart J 2019; 40:87-165. PUBMED | CROSSREF

8. Patel MR, Peterson ED, Dai D, et al. Low diagnostic yield of elective coronary angiography. N Engl J Med 2010;362:886-95. PUBMED | CROSSREF

9. Park SJ, Kang SJ, Ahn JM, et al. Visual-functional mismatch between coronary angiography and fractional flow reserve. JACC Cardiovasc Interv 2012;5:1029-36.

PUBMED | CROSSREF 
10. Fischer JJ, Samady H, McPherson JA, et al. Comparison between visual assessment and quantitative angiography versus fractional flow reserve for native coronary narrowings of moderate severity. Am J Cardiol 2002;90:210-5. PUBMED | CROSSREF

11. Christou MA, Siontis GC, Katritsis DG, Ioannidis JP. Meta-analysis of fractional flow reserve versus quantitative coronary angiography and noninvasive imaging for evaluation of myocardial ischemia. $\mathrm{AmJ}$ Cardiol 2007;99:450-6. PUBMED | CROSSREF

12. Hodgson JM, Graham SP, Savakus AD, et al. Clinical percutaneous imaging of coronary anatomy using an over-the-wire ultrasound catheter system. Int J Card Imaging 1989;4:187-93. PUBMED | CROSSREF

13. Yabushita H, Bouma BE, Houser SL, et al. Characterization of human atherosclerosis by optical coherence tomography. Circulation 2002;106:1640-5. PUBMED | CROSSREF

14. Kubo T, Akasaka T, Shite J, et al. OCT compared with IVUS in a coronary lesion assessment: the OPUSCLASS study. JACC Cardiovasc Imaging 2013;6:1095-104. PUBMED | CROSSREF

15. Kim IC, Nam CW, Cho YK, et al. Discrepancy between frequency domain optical coherence tomography and intravascular ultrasound in human coronary arteries and in a phantom in vitro coronary model. Int J Cardiol 2016;221:860-6. PUBMED | CROSSREF

16. Mintz GS, Painter JA, Pichard AD, et al. Atherosclerosis in angiographically "normal" coronary artery reference segments: an intravascular ultrasound study with clinical correlations. J Am Coll Cardiol 1995;25:1479-85. PUBMED | CROSSREF

17. Kobayashi $\mathrm{Y}$, Okura H, Kume T, et al. Impact of target lesion coronary calcification on stent expansion. Circ J 2014;78:2209-14 PUBMED | CROSSREF

18. Karimi Galougahi K, Shlofmitz RA, Ben-Yehuda O, et al. Guiding light: insights into atherectomy by optical coherence tomography. JACC Cardiovasc Interv 2016;9:2362-3. PUBMED | CROSSREF

19. Maejima N, Hibi K, Saka K, et al. Relationship between thickness of calcium on optical coherence tomography and crack formation after balloon dilatation in calcified plaque requiring rotational atherectomy. Circ J 2016;80:1413-9. PUBMED | CROSSREF

20. Fujino A, Mintz GS, Matsumura M, et al. A new optical coherence tomography-based calcium scoring system to predict stent underexpansion. EuroIntervention 2018;13:e2182-9. PUBMED | CROSSREF

21. Tanaka A, Imanishi T, Kitabata $\mathrm{H}$, et al. Lipid-rich plaque and myocardial perfusion after successful stenting in patients with non-ST-segment elevation acute coronary syndrome: an optical coherence tomography study. Eur Heart J 2009;30:1348-55. PUBMED | CROSSREF

22. Yonetsu T, Kakuta T, Lee T, et al. Impact of plaque morphology on creatine kinase-MB elevation in patients with elective stent implantation. Int J Cardiol 2011;146:80-5. PUBMED | CROSSREF

23. Lee $\mathrm{T}$, Yonetsu $\mathrm{T}$, Koura $\mathrm{K}$, et al. Impact of coronary plaque morphology assessed by optical coherence tomography on cardiac troponin elevation in patients with elective stent implantation. Circ Cardiovasc Interv 2011;4:378-86. PUBMED | CROSSREF

24. Porto I, Di Vito L, Burzotta F, et al. Predictors of periprocedural (type IVa) myocardial infarction, as assessed by frequency-domain optical coherence tomography. Circ Cardiovasc Interv 2012;5:89-96, S1-6. PUBMED | CROSSREF

25. Imola F, Occhipinti M, Biondi-Zoccai G, et al. Association between proximal stent edge positioning on atherosclerotic plaques containing lipid pools and postprocedural myocardial infarction (from the CLIPOOL Study). Am J Cardiol 2013;111:526-31. PUBMED | CROSSREF

26. Ikenaga H, Ishihara M, Inoue I, et al. Longitudinal extent of lipid pool assessed by optical coherence tomography predicts microvascular no-reflow after primary percutaneous coronary intervention for STsegment elevation myocardial infarction. J Cardiol 2013;62:71-6. PUBMED | CROSSREF 
27. Kini AS, Motoyama S, Vengrenyuk Y, et al. Multimodality intravascular imaging to predict periprocedural myocardial infarction during percutaneous coronary intervention. JACC Cardiovasc Interv 2015;8:937-45. PUBMED | CROSSREF

28. Okabe T, Mintz GS, Buch AN, et al. Intravascular ultrasound parameters associated with stent thrombosis after drug-eluting stent deployment. Am J Cardiol 2007;100:615-20. PUBMED | CROSSREF

29. Liu X, Doi H, Maehara A, et al. A volumetric intravascular ultrasound comparison of early drug-eluting stent thrombosis versus restenosis. JACC Cardiovasc Interv 2009;2:428-34. PUBMED | CROSSREF

30. Choi SY, Witzenbichler B, Maehara A, et al. Intravascular ultrasound findings of early stent thrombosis after primary percutaneous intervention in acute myocardial infarction: a Harmonizing Outcomes with Revascularization and Stents in Acute Myocardial Infarction (HORIZONS-AMI) substudy. Circ Cardiovasc Interv 2011;4:239-47. PUBMED | CROSSREF

31. Sakurai R, Ako J, Morino Y, et al. Predictors of edge stenosis following sirolimus-eluting stent deployment (a quantitative intravascular ultrasound analysis from the SIRIUS trial). Am J Cardiol 2005;96:1251-3. PUBMED | CROSSREF

32. Liu J, Maehara A, Mintz GS, et al. An integrated TAXUS IV, V, and VI intravascular ultrasound analysis of the predictors of edge restenosis after bare metal or paclitaxel-eluting stents. Am J Cardiol 2009;103:501-6. PUBMED | CROSSREF

33. Costa MA, Angiolillo DJ, Tannenbaum M, et al. Impact of stent deployment procedural factors on longterm effectiveness and safety of sirolimus-eluting stents (final results of the multicenter prospective STLLR trial). Am J Cardiol 2008;101:1704-11. PUBMED | CROSSREF

34. Kang SJ, Cho YR, Park GM, et al. Intravascular ultrasound predictors for edge restenosis after newer generation drug-eluting stent implantation. Am J Cardiol 2013;111:1408-14. PUBMED | CROSSREF

35. Kobayashi N, Mintz GS, Witzenbichler B, et al. Prevalence, features, and prognostic importance of edge dissection after drug-eluting stent implantation: an ADAPT-DES intravascular ultrasound substudy. Circ Cardiovasc Interv 2016;9:e003553. PUBMED | CROSSREF

36. Calvert PA, Brown AJ, Hoole SP, Obaid DR, West NE, Bennett MR. Geographical miss is associated with vulnerable plaque and increased major adverse cardiovascular events in patients with myocardial infarction. Catheter Cardiovasc Interv 2016;88:340-7. PUBMED | CROSSREF

37. Ali ZA, Maehara A, Généreux P, et al. Optical coherence tomography compared with intravascular ultrasound and with angiography to guide coronary stent implantation (ILUMIEN III: OPTIMIZE PCI): a randomised controlled trial. Lancet 2016;388:2618-28. PUBMED | CROSSREF

38. Kubo T, Shinke T, Okamura T, et al. Optical frequency domain imaging vs. intravascular ultrasound in percutaneous coronary intervention (OPINION trial): one-year angiographic and clinical results. Eur Heart J2017;38:3139-47. PUBMED | CROSSREF

39. van der Sijde JN, Guagliumi G, Sirbu V, et al. The OPTIS Integrated System: real-time, co-registration of angiography and optical coherence tomography. EuroIntervention 2016;12:855-60. PUBMED | CROSSREF

40. Fujii K, Carlier SG, Mintz GS, et al. Stent underexpansion and residual reference segment stenosis are related to stent thrombosis after sirolimus-eluting stent implantation: an intravascular ultrasound study. $J$ Am Coll Cardiol 2005;45:995-8. PUBMED | CROSSREF

41. Hong MK, Mintz GS, Lee CW, et al. Intravascular ultrasound predictors of angiographic restenosis after sirolimus-eluting stent implantation. Eur HeartJ 2006;27:1305-10. PUBMED | CROSSREF

42. Morino Y, Honda Y, Okura H, et al. An optimal diagnostic threshold for minimal stent area to predict target lesion revascularization following stent implantation in native coronary lesions. Am J Cardiol 2001;88:301-3. PUBMED | CROSSREF 
43. Doi H, Maehara A, Mintz GS, et al. Impact of post-intervention minimal stent area on 9-month follow-up patency of paclitaxel-eluting stents: an integrated intravascular ultrasound analysis from the TAXUS IV, V, and VI and TAXUS ATLAS Workhorse, Long Lesion, and Direct Stent Trials. JACC Cardiovasc Interv 2009;2:1269-75. PUBMED | CROSSREF

44. Sonoda S, Morino Y, Ako J, et al. Impact of final stent dimensions on long-term results following sirolimus-eluting stent implantation: serial intravascular ultrasound analysis from the sirius trial. J Am Coll Cardiol 2004;43:1959-63. PUBMED | CROSSREF

45. Meneveau N, Souteyrand G, Motreff P, et al. Optical coherence tomography to optimize results of percutaneous coronary intervention in patients with non-ST-elevation acute coronary syndrome: results of the multicenter, randomized DOCTORS Study (Does Optical Coherence Tomography Optimize Results of Stenting). Circulation 2016;134:906-17. PUBMED | CROSSREF

46. Prati F, Romagnoli E, Burzotta F, et al. Clinical impact of OCT findings during PCI: the CLI-OPCI II study. JACC Cardiovasc Imaging 2015;8:1297-305. PUBMED | CROSSREF

47. de Jaegere P, Mudra H, Figulla H, et al. Intravascular ultrasound-guided optimized stent deployment. Immediate and 6 months clinical and angiographic results from the Multicenter Ultrasound Stenting in Coronaries Study (MUSIC Study). Eur Heart J1998;19:1214-23. PUBMED | CROSSREF

48. Hong SJ, Kim BK, Shin DH, et al. Effect of intravascular ultrasound-guided vs angiography-guided everolimus-eluting stent implantation: the IVUS-XPL randomized clinical trial. JAMA 2015;314:2155-63. PUBMED | CROSSREF

49. Jakabcin J, Spacek R, Bystron M, et al. Long-term health outcome and mortality evaluation after invasive coronary treatment using drug eluting stents with or without the IVUS guidance. Randomized control trial. HOME DES IVUS. Catheter Cardiovasc Interv 2010;75:578-83. PUBMED | CROSSREF

50. Jang IK, Tearney G, Bouma B. Visualization of tissue prolapse between coronary stent struts by optical coherence tomography: comparison with intravascular ultrasound. Circulation 2001;104:2754. PUBMED | CROSSREF

51. Futamatsu H, Sabaté M, Angiolillo DJ, et al. Characterization of plaque prolapse after drug-eluting stent implantation in diabetic patients: a three-dimensional volumetric intravascular ultrasound outcome study. J Am Coll Cardiol 2006;48:1139-45. PUBMED | CROSSREF

52. Kubo T, Imanishi $\mathrm{T}$, Kitabata $\mathrm{H}$, et al. Comparison of vascular response after sirolimus-eluting stent implantation between patients with unstable and stable angina pectoris: a serial optical coherence tomography study. JACC Cardiovasc Imaging 2008;1:475-84. PUBMED | CROSSREF

53. Gonzalo N, Serruys PW, Okamura T, et al. Optical coherence tomography assessment of the acute effects of stent implantation on the vessel wall: a systematic quantitative approach. Heart 2009;95:1913-9. PUBMED | CROSSREF

54. Hong YJ, Jeong MH, Choi YH, et al. Impact of tissue prolapse after stent implantation on short- and longterm clinical outcomes in patients with acute myocardial infarction: an intravascular ultrasound analysis. Int J Cardiol 2013;166:646-51. PUBMED | CROSSREF

55. Jin QH, Chen YD, Jing J, et al. Incidence, predictors, and clinical impact of tissue prolapse after coronary intervention: an intravascular optical coherence tomography study. Cardiology 2011;119:197-203. PUBMED | CROSSREF

56. Sohn J, Hur SH, Kim IC, et al. A comparison of tissue prolapse with optical coherence tomography and intravascular ultrasound after drug-eluting stent implantation. Int J Cardiovasc Imaging 2015;31:21-9. PUBMED | CROSSREF

57. Soeda T, Uemura S, Park SJ, et al. Incidence and clinical significance of poststent optical coherence tomography findings: one-year follow-up study from a multicenter registry. Circulation 2015;132:1020-9. PUBMED | CROSSREF

58. Cheneau E, Leborgne L, Mintz GS, et al. Predictors of subacute stent thrombosis: results of a systematic intravascular ultrasound study. Circulation 2003;108:43-7. PUBMED | CROSSREF 
59. Hong YJ, Jeong MH, Ahn Y, et al. Plaque prolapse after stent implantation in patients with acute myocardial infarction: an intravascular ultrasound analysis. JACC Cardiovasc Imaging 2008;1:489-97. PUBMED | CROSSREF

60. Sugiyama T, Kimura S, Akiyama D, et al. Quantitative assessment of tissue prolapse on optical coherence tomography and its relation to underlying plaque morphologies and clinical outcome in patients with elective stent implantation. Int J Cardiol 2014;176:182-90.

PUBMED | CROSSREF

61. Qiu F, Mintz GS, Witzenbichler B, et al. Prevalence and clinical impact of tissue protrusion after stent implantation: an ADAPT-DES intravascular ultrasound substudy. JACC Cardiovasc Interv 2016;9:1499-507. PUBMED | CROSSREF

62. Prati F, Di Vito L, Biondi-Zoccai G, et al. Angiography alone versus angiography plus optical coherence tomography to guide decision-making during percutaneous coronary intervention: the Centro per la Lotta contro l'Infarto-Optimisation of Percutaneous Coronary Intervention (CLI-OPCI) study. EuroIntervention 2012;8:823-9. PUBMED | CROSSREF

63. Maehara A, Matsumura M, Mintz GS. Assessment and quantitation of stent results by intracoronary optical coherence tomography. Interv Cardiol Clin 2015;4:285-94. PUBMED

64. Guo N, Maehara A, Mintz GS, et al. Incidence, mechanisms, predictors, and clinical impact of acute and late stent malapposition after primary intervention in patients with acute myocardial infarction: an intravascular ultrasound substudy of the Harmonizing Outcomes with Revascularization and Stents in Acute Myocardial Infarction (HORIZONS-AMI) trial. Circulation 2010;122:1077-84. PUBMED | CROSSREF

65. Steinberg DH, Mintz GS, Mandinov L, et al. Long-term impact of routinely detected early and late incomplete stent apposition: an integrated intravascular ultrasound analysis of the TAXUS IV, V, and VI and TAXUS ATLAS workhorse, long lesion, and direct stent studies. JACC Cardiovasc Interv 2010;3:486-94. PUBMED | CROSSREF

66. Souteyrand G, Amabile N, Mangin L, et al. Mechanisms of stent thrombosis analysed by optical coherence tomography: insights from the national PESTO French registry. Eur HeartJ 2016;37:1208-16. PUBMED | CROSSREF

67. Adriaenssens T, Joner M, Godschalk TC, et al. Optical coherence tomography findings in patients with coronary stent thrombosis: a report of the PRESTIGE consortium (Prevention of Late Stent Thrombosis by an Interdisciplinary Global European Effort). Circulation 2017;136:1007-21. PUBMED | CROSSREF

68. Shlofmitz E, Shlofmitz RA, Galougahi KK, et al. Algorithmic approach for optical coherence tomographyguided stent implantation during percutaneous coronary intervention. Interv Cardiol Clin 2018;7:329-44. PUBMED

69. Antonsen L, Thayssen P, Maehara A, et al. Optical Coherence Tomography Guided Percutaneous Coronary Intervention with Nobori Stent Implantation in Patients with Non-ST-Segment-Elevation Myocardial Infarction (OCTACS) Trial: difference in strut coverage and dynamic malapposition patterns at 6 months. Circ Cardiovasc Interv 2015;8:e002446. PUBMED | CROSSREF

70. Imola F, Mallus MT, Ramazzotti V, et al. Safety and feasibility of frequency domain optical coherence tomography to guide decision making in percutaneous coronary intervention. EuroIntervention 2010;6:575-81. PUBMED | CROSSREF

71. Nijjer SS, Sen S, Petraco R, Mayet J, Francis DP, Davies JE. The Instantaneous wave-Free Ratio (iFR) pullback: a novel innovation using baseline physiology to optimise coronary angioplasty in tandem lesions. Cardiovasc Revasc Med 2015;16:167-71.

PUBMED | CROSSREF

72. Romagnoli E, Sangiorgi GM, Cosgrave J, Guillet E, Colombo A. Drug-eluting stenting: the case for postdilation. JACC Cardiovasc Interv 2008;1:22-31. PUBMED | CROSSREF

73. Lee SY, Kim JS, Yoon HJ, et al. Early strut coverage in patients receiving drug-eluting stents and its implications for dual antiplatelet therapy: a randomized trial. JACC Cardiovasc Imaging 2018;11:1810-9. PUBMED | CROSSREF

74. Habara M, Nasu K, Terashima M, et al. Impact of frequency-domain optical coherence tomography guidance for optimal coronary stent implantation in comparison with intravascular ultrasound guidance. Circ Cardiovasc Interv 2012;5:193-201. PUBMED | CROSSREF 
75. Maehara A, Ben-Yehuda O, Ali Z, et al. Comparison of stent expansion guided by optical coherence tomography versus intravascular ultrasound: the ILUMIEN II Study (Observational Study of Optical Coherence Tomography [OCT] in Patients Undergoing Fractional Flow Reserve [FFR] and Percutaneous Coronary Intervention). JACC Cardiovasc Interv 2015;8:1704-14. PUBMED | CROSSREF

76. Otake H, Kubo T, Takahashi H, et al. Optical Frequency Domain Imaging versus Intravascular Ultrasound in Percutaneous Coronary Intervention (OPINION Trial): results from the OPINION imaging study. JACC Cardiovasc Imaging 2018;11:111-23. PUBMED | CROSSREF

77. Wijns W, Shite J, Jones MR, et al. Optical coherence tomography imaging during percutaneous coronary intervention impacts physician decision-making: ILUMIEN I study. Eur Heart J 2015;36:3346-55. PUBMED | CROSSREF

78. Jones DA, Rathod KS, Koganti S, et al. Angiography alone versus angiography plus optical coherence tomography to guide percutaneous coronary intervention: outcomes from the Pan-London PCI cohort. JACC Cardiovasc Interv 2018;11:1313-21. PUBMED | CROSSREF

79. Iannaccone M, D'Ascenzo F, Frangieh AH, et al. Impact of an optical coherence tomography guided approach in acute coronary syndromes: a propensity matched analysis from the international FORMIDABLE-CARDIOGROUP IV and USZ registry. Catheter Cardiovasc Interv 2017;90:E46-52. PUBMED | CROSSREF

80. Kim IC, Yoon HJ, Shin ES, et al. Usefulness of frequency domain optical coherence tomography compared with intravascular ultrasound as a guidance for percutaneous coronary intervention. J Interv Cardiol 2016;29:216-24. PUBMED | CROSSREF

81. Tearney GJ, Regar E, Akasaka T, et al. Consensus standards for acquisition, measurement, and reporting of intravascular optical coherence tomography studies: a report from the International Working Group for Intravascular Optical Coherence Tomography Standardization and Validation. J Am Coll Cardiol 2012;59:1058-72. PUBMED | CROSSREF

82. Mailloux L, Swartz CD, Capizzi R, et al. Acute renal failure after administration of low-molecular weight dextran. N Engl J Med 1967;277:1113-8. PUBMED | CROSSREF

83. Okamura T, Onuma Y, Yamada J, et al. 3D optical coherence tomography: new insights into the process of optimal rewiring of side branches during bifurcational stenting. EuroIntervention 2014;10:907-15. PUBMED | CROSSREF

84. Francaviglia B, Capranzano P, Gargiulo G, et al. Usefulness of 3D OCT to diagnose a noncircumferential open-cell stent fracture. JACC Cardiovasc Imaging 2016;9:210-1.

PUBMED | CROSSREF 